NASA/TM-2004-213396

\title{
Noise Benefits of Increased Fan Bypass Nozzle Area
}

Richard P. Woodward and Christopher E. Hughes

Glenn Research Center, Cleveland, Ohio 
Since its founding, NASA has been dedicated to the advancement of aeronautics and space science. The NASA Scientific and Technical Information (STI) Program Office plays a key part in helping NASA maintain this important role.

The NASA STI Program Office is operated by Langley Research Center, the Lead Center for NASA's scientific and technical information. The NASA STI Program Office provides access to the NASA STI Database, the largest collection of aeronautical and space science STI in the world. The Program Office is also NASA's institutional mechanism for disseminating the results of its research and development activities. These results are published by NASA in the NASA STI Report Series, which includes the following report types:

- TECHNICAL PUBLICATION. Reports of completed research or a major significant phase of research that present the results of NASA programs and include extensive data or theoretical analysis. Includes compilations of significant scientific and technical data and information deemed to be of continuing reference value. NASA's counterpart of peerreviewed formal professional papers but has less stringent limitations on manuscript length and extent of graphic presentations.

- TECHNICAL MEMORANDUM. Scientific and technical findings that are preliminary or of specialized interest, e.g., quick release reports, working papers, and bibliographies that contain minimal annotation. Does not contain extensive analysis.

- CONTRACTOR REPORT. Scientific and technical findings by NASA-sponsored contractors and grantees.
- CONFERENCE PUBLICATION. Collected papers from scientific and technical conferences, symposia, seminars, or other meetings sponsored or cosponsored by NASA.

- SPECIAL PUBLICATION. Scientific, technical, or historical information from NASA programs, projects, and missions, often concerned with subjects having substantial public interest.

- TECHNICAL TRANSLATION. Englishlanguage translations of foreign scientific and technical material pertinent to NASA's mission.

Specialized services that complement the STI Program Office's diverse offerings include creating custom thesauri, building customized databases, organizing and publishing research results ... even providing videos.

For more information about the NASA STI Program Office, see the following:

- Access the NASA STI Program Home Page at http://www.sti.nasa.gov

- E-mail your question via the Internet to help@sti.nasa.gov

- Fax your question to the NASA Access Help Desk at 301-621-0134

- Telephone the NASA Access Help Desk at 301-621-0390

- Write to:

NASA Access Help Desk

NASA Center for AeroSpace Information 7121 Standard Drive

Hanover, MD 21076 
NASA/TM-2004-213396

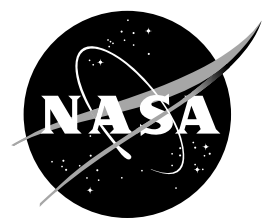

\section{Noise Benefits of Increased Fan Bypass Nozzle Area}

Richard P. Woodward and Christopher E. Hughes

Glenn Research Center, Cleveland, Ohio

Prepared for the

43rd Aerospace Sciences Meeting and Exhibit

sponsored by the American Institute of Aeronautics and Astronautics

Reno, Nevada, January 10-13, 2005

National Aeronautics and

Space Administration

Glenn Research Center 
Available from

NASA Center for Aerospace Information 7121 Standard Drive

Hanover, MD 21076
National Technical Information Service 5285 Port Royal Road Springfield, VA 22100

Available electronically at http://gltrs.grc.nasa.gov 


\title{
Noise Benefits of Increased Fan Bypass Nozzle Area
}

\author{
Richard P. Woodward and Christopher E. Hughes \\ National Aeronautics and Space Administration \\ Glenn Research Center \\ Cleveland, Ohio 44135
}

\begin{abstract}
An advanced model turbofan (typical of current engine technology) was tested in the NASA Glenn 9- by 15-Foot Low Speed Wind Tunnel (9- by 15-Foot LSWT) to explore far field acoustic effects of increased bypass nozzle area. This fan stage test was part of the NASA Glenn Fan Broadband Source Diagnostic Test, second entry (SDT2) which acquired aeroacoustic results over a range of test conditions. The baseline nozzle was sized to produce maximum stage performance for the engine at a high altitude, cruise point condition. However, the wind tunnel testing is conducted near sea level conditions. Therefore, in order to simulate and obtain performance at other aircraft operating conditions, two additional nozzles were designed and tested-one with a +5 percent increase in weight flow (+5.4 percent increase in nozzle area compared with the baseline nozzle), sized to simulate the performance at the stage design point conditions, and the other with a +7.5 percent increase in weight flow (+10.9 percent increase in nozzle area), sized for maximum weight flow with a fixed nozzle at sea level conditions. Measured acoustic benefits with increased nozzle area were very encouraging, showing overall sound power level (OAPWL) reductions of 2 or more $\mathrm{dB}$ while the stage thrust actually increased by several percentage points except for the most open nozzle at takeoff rotor speed where stage performance decreased. These noise reduction benefits were seen to primarily affect broadband noise, and were evident throughout the range of measured sideline angles.
\end{abstract}

\section{Introduction}

An advanced model turbofan was tested in the NASA Glenn 9- by 15-Foot Low Speed Wind Tunnel (9- by 15-Foot LSWT) to explore far field acoustic effects of increased bypass nozzle area. This fan stage test was part of the NASA Glenn Fan Broadband Source Diagnostic Test, second entry (SDT2) (refs. 1 to 6 present results from the first entry of the Fan Source Diagnostic Test), which acquired aeroacoustic results over a range of test conditions. The 9- by 15-Foot LSWT provides a low turbulence, anechoic test environment for model turbofan aeroacoustic tests. $^{7-9}$ The baseline nozzle was sized for sea level takeoff conditions. Two additional nozzles were also testedwith a +5 percent increase in flow, corresponding to a +5.4 percent increase in area (sized for design point conditions at 100 percent rotor speed) and a +7.5 percent increase in flow, corresponding to a +10.9 percent increase in area (sized for maximum flow with a fixed nozzle at sea level conditions). Measured acoustic benefits with increased nozzle area were very encouraging, showing overall sound power level (OAPWL) reductions of 2 or more $\mathrm{dB}$ while the stage thrust actually increased by several percentage points. These noise reduction benefits were primarily for the broadband noise, and were evident throughout the range of measured sideline angles.

Earlier fan noise tests reported in the literature have shown the potential for significant reductions in broadband noise levels associated with increased bypass nozzle flow (increased area or reduced throttling). Reference 10 presents results for a 6 foot diameter fan which was tested in the NASA Glenn Quiet Fan Facility. The fan, designated QF-6 had a relatively low 1.2 stage pressure ratio and design rotor tip speed (750 ft/s), and represented early 1970's turbofan design. There was no consideration of inflow turbulence control for this test. However, results for QF-6 showed that the far field broadband sound pressure level (SPL) decreased by $4 \mathrm{~dB}$ or more as the stage exit nozzle area increased from 95 to 105 percent of design. The Overall Sound Power Level (OAPWL) showed a similar decrease as the nozzle area was increased. This was accompanied with an increase in the stage adiabatic efficiency with increased nozzle area. This noise reduction with increased bypass nozzle area was repeated for another fan ${ }^{11}$ (QF-2) tested in the NASA Quiet Fan Facility. QF-2 was a 1.5 stage pressure ratio, $1107 \mathrm{ft} / \mathrm{s}$ tip speed fan which likewise represented 1970 turbofan technology. References 12 and 13 present forward arc acoustic results for fans statically tested in anechoic facilities using inflow control devices to minimize inlet turbulence. Acoustic 
results for these two tests also suggested that broadband noise levels may be reduced as the stage flow is increased through reduced downstream throttling (analogous to increased bypass nozzle area). Ginder and Newby ${ }^{14}$ considered forward arc acoustic results for several fans statically tested in an anechoic facility with inflow control as well as the QF-6 results of reference 10. They concluded that the fan stage broadband noise levels were related to changes in the rotor leading edge incidence, which changed with the stage nozzle area or flow. They concluded that the maximum fan stage broadband noise level changed by about $1.7 \mathrm{~dB}$ per degree change in the rotor incidence angle.

Reductions in turbofan noise levels are an important component of current efforts to reduce overall jet aircraft noise levels. The NASA Glenn Fan Broadband Source Diagnostic Test series provided the opportunity to re-evaluate the potential for fan stage broadband noise reduction for a current technology turbofan. Likewise, the test facility environment enabled taking far-field acoustic data for the entire fan stage (inlet and exhaust) in an anechoic, low turbulence wind tunnel environment simulating takeoff/approach conditions.

\section{Description of Model Turbofan Test}

\section{A. Research Hardware}

Results presented herein are for the SDT2 fan stage with the baseline, R4 rotor and baseline radial stator (table 1). The R4 rotor had 22 blades and a nominal 22 in. diameter. The baseline radial stator had 54 blades, thus was cutoff for the fundamental rotor-stator interaction tone. ${ }^{15}$ Figure 1 is a photograph of the R4 rotor, and figure 2 is a photograph of the baseline stator. Figure 3 is a cross sectional sketch of the research fan stage with the R4 rotor and baseline stator, and a photograph of the rotor and stator without the nacelle installed in the wind tunnel. The rotor-stator spacing is a nominal 2.5 axial rotor chords.

Table 1.-SDT2 research fan stage design parameters.

\begin{tabular}{|l|c|}
\multicolumn{2}{|c}{ R4 Rotor } \\
\hline No. of blades & 22 \\
\hline Tip diameter, in. & 22 \\
\hline Inlet radius ratio & 0.30 \\
\hline Corrected design speed, RPM & 12,657 \\
\hline Design tip speed, ft/s & 1,215 \\
\hline Corrected weight flow, lbm/s & 100.5 \\
\hline Specific flow, lbm/s-ft ${ }^{2}$ & 41.8 \\
\hline Stage pressure ratio & 1.47 \\
\hline
\end{tabular}

\section{Baseline Stator}

\begin{tabular}{|c|c|c|c|}
\hline No. vanes & L. E. sweep & Aspect ratio & Solidity \\
\hline 54 & $0^{\circ}$ & 3.51 & 1.52 \\
\hline
\end{tabular}

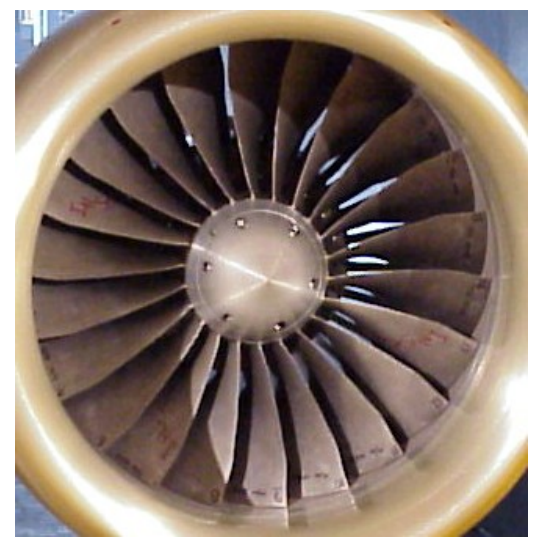

Figure 1.-Photograph of R4 rotor.

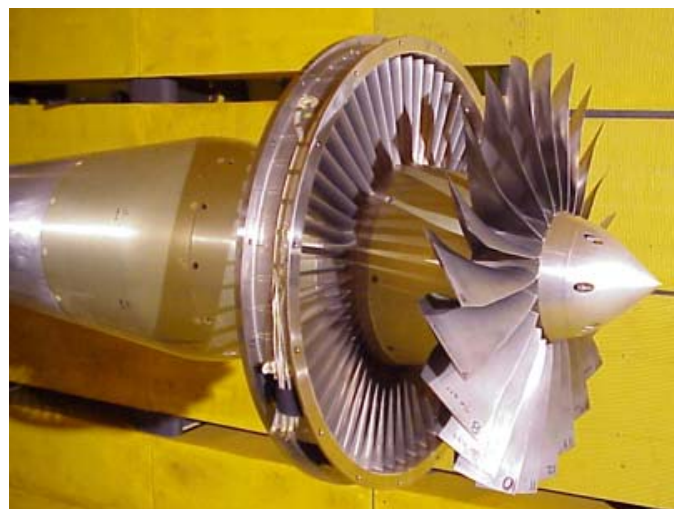

Figure 2.-Photograph of baseline radial stator. 


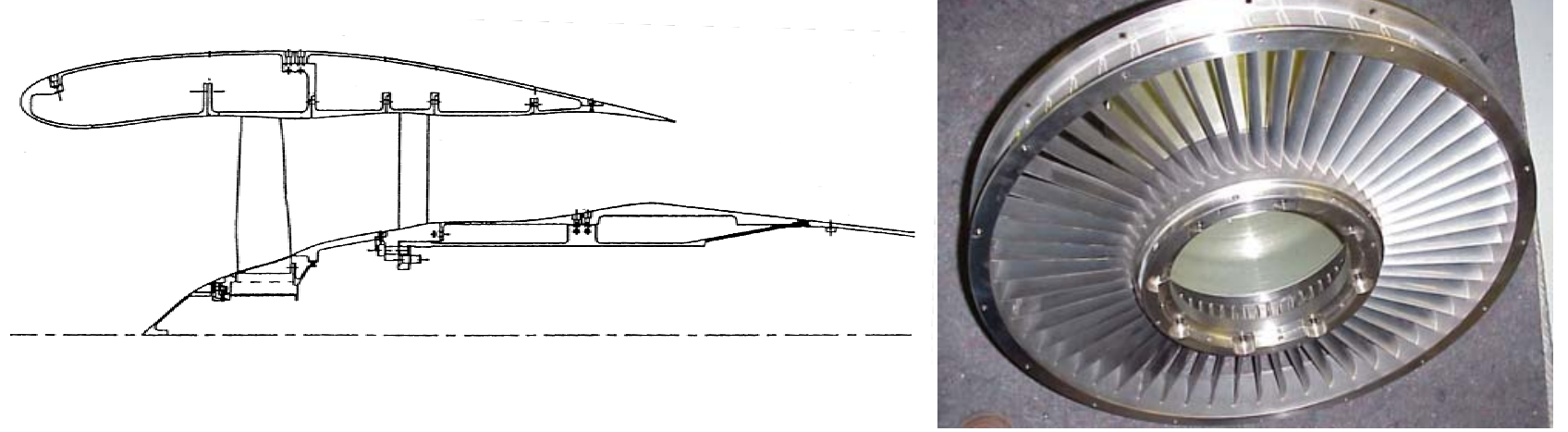

Figure 3.-Cross sectional sketch and photograph of test fan stage with $\mathrm{R} 4$ rotor and baseline stator.

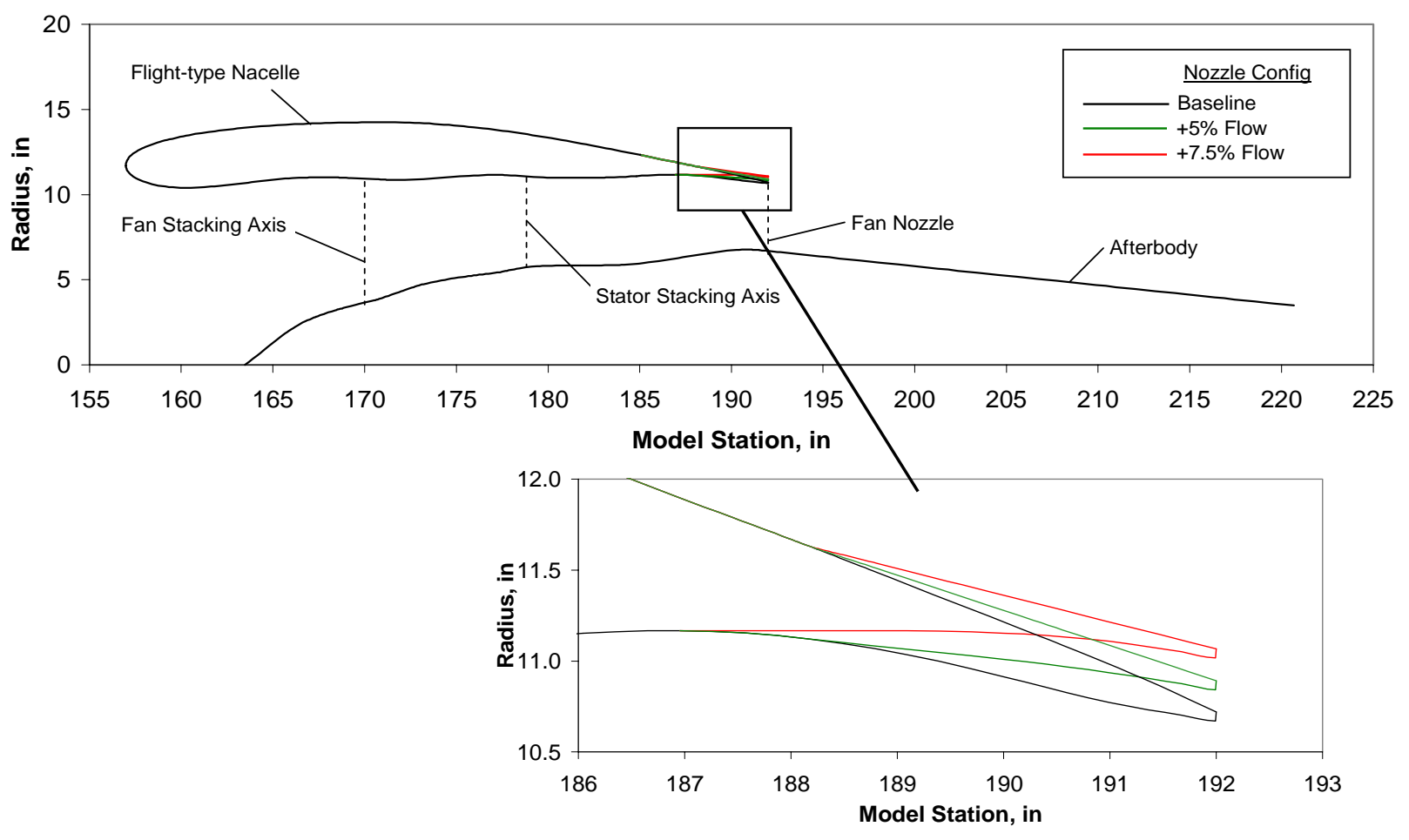

Figure 4.-Sketch of bypass nozzle geometry configurations.

There were three fixed-area stage bypass nozzles designed for testing. Each nozzle was designed to reach a specific operating condition on the rotor and stage operating maps. The fixed-area, "flight-type" engine nozzles are typically sized to maximize engine efficiency cruise conditions at cruise altitude. The three bypass nozzles used for this test were designed as follows: 1) A minimum flow-baseline nozzle, used as the nozzle design for all acoustic testing, and designed to achieve minimum stator pressure losses and maximum thrust at take-off conditions without sacrificing cruise operating performance, 2) A design point nozzle, which allowed a +5 percent increase in weight flow with a +5.4 percent increase in nozzle area compared to the baseline nozzle over the fan stage operating range in order to achieve the design point fan weight flow and pressure ratio conditions at 100 percent corrected rotor design speed, and 3) A high flow nozzle, which allowed the maximum weight flow possible through the fan at sea level conditions or +7.5 percent above the baseline nozzle with a 10.9 percent increase in nozzle area. The purpose was to determine the effect of reduced rotor blade loading and increased nozzle exit velocity on the fan stage performance and acoustics over a range of operating conditions that would be seen for this particular design in an engine application. Each of the bypass nozzles allowed a different fan stage operating line at sea level conditions. A sketch of the three bypass nozzle geometries is shown in figure 4. 


\section{B. Anechoic Wind Tunnel and Acoustic Instrumentation}

The NASA Glenn 9- by 15-Foot LSWT is located in the low speed return leg of the 8- by 6-Foot Supersonic Wind Tunnel. The tunnel test section walls, floor, and ceiling have acoustic treatment to produce an anechoic test environment. Figure 5 is a sketch of the research fan stage installed in the 9- by 15-Foot LSWT. Sideline acoustic data were acquired with a computer-controlled translating microphone probe and with three aft microphone assemblies mounted to the tunnel floor. The translating microphone probe acquired data at 48 sideline geometric angles from 27.2 to $134.6^{\circ}$ relative to the rotor plane. The translating probe traverse was $89 \mathrm{in}$. from the rotor rotational axis (about four rotor diameters). Acoustic data taken at this sideline distance are representative of far-field conditions, although there are still manifestations of near field inlet/exhaust noise lobes. A wall-mounted microphone probe was placed at a reference location adjacent to the translating probe home position $\left(134.6^{\circ}\right.$, maximum aft travel). The three fixed microphone assemblies were mounted at the home axial position to acquire aft acoustic data at geometric angles of 140,150 , and $160^{\circ}$. Data were also acquired with an acoustic barrier wall installed adjacent to the fan stage which effectively blocked aft-radiated noise, allowing for measurement of only the inlet-radiated noise (fig. 6). The acoustic data were acquired through a digital computer system and stored for post-run analysis.

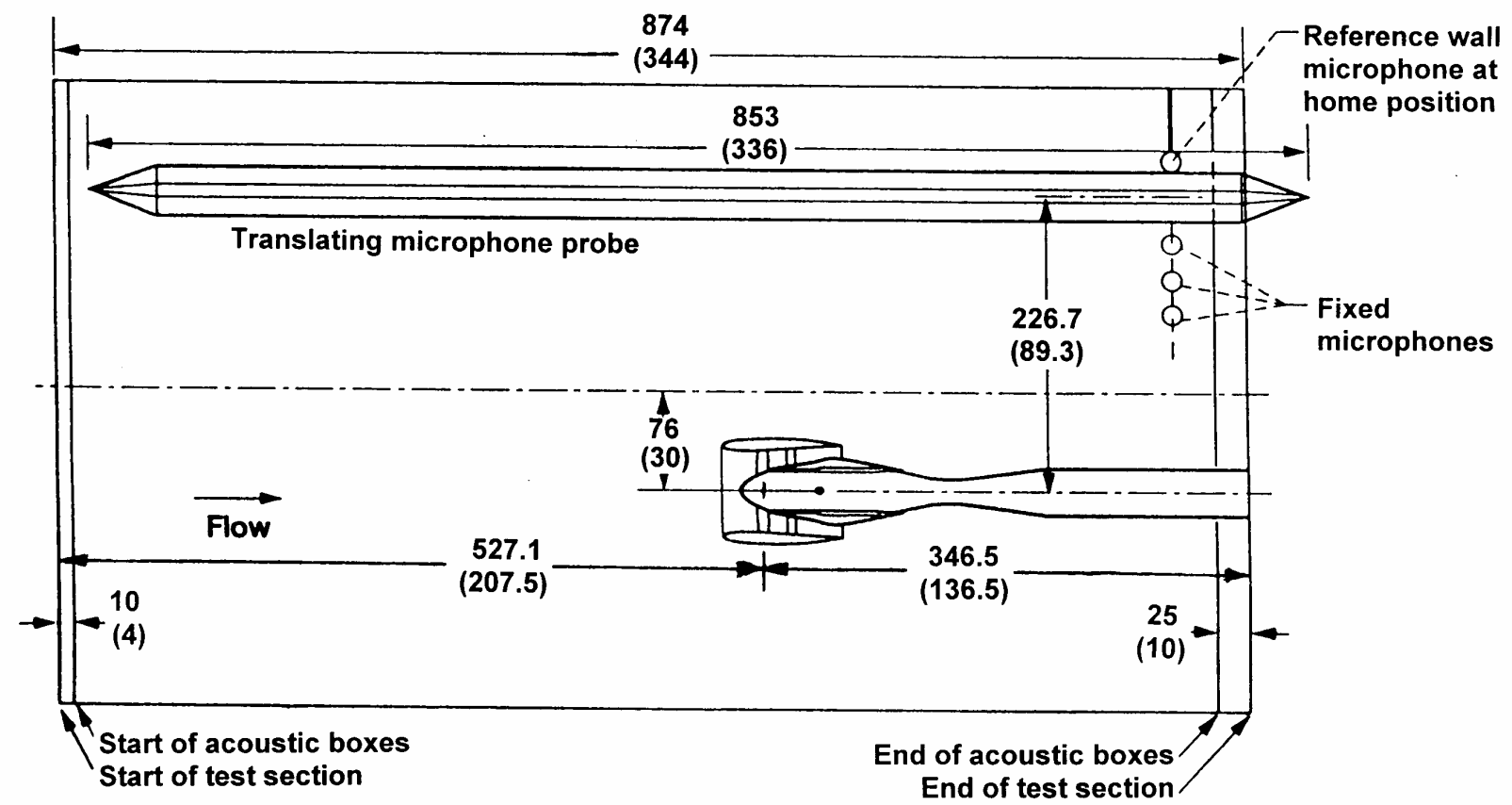

Figure 5.- Sketch of the model fan stage installed in the 9- by 15- Foot LSWT. Far-field acoustic data were acquired with a translating microphone probe and aft fixed microphones (dimensions in $\mathrm{cm}$ (in.)).

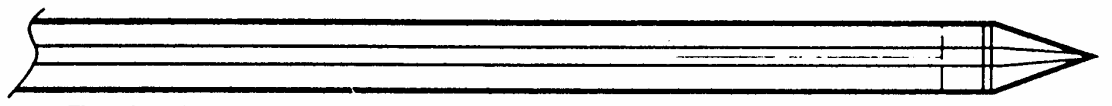

Track microphone probe

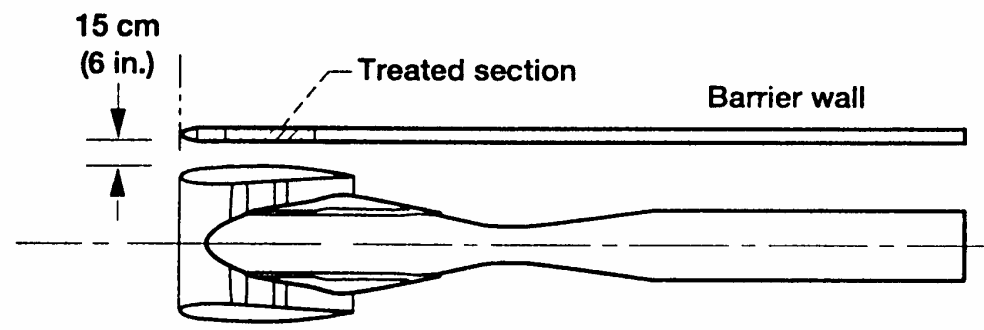

Figure 6. - Sketch showing location of acoustic barrier wall relative to model fan stage (dimensions in cm (in.)). 


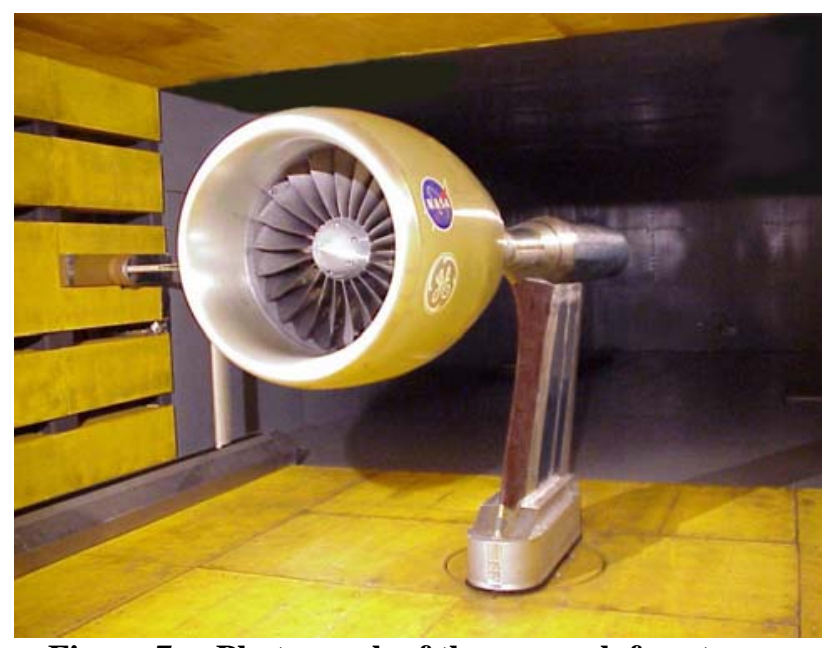

Figure 7.—Photograph of the research fan stage installed in the 9- by 15-Foot LSWT.
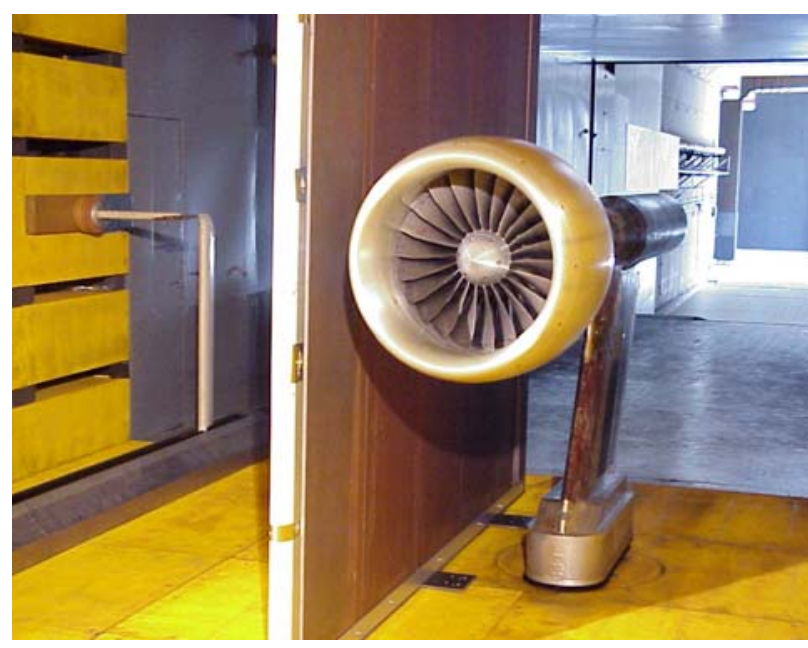

Figure 8.-Photograph of the research fan stage with the acoustic barrier wall in place.

Figure 7 is a photograph of the research fan stage installed in the 9- by 15-Foot LSWT. Figure 8 shows the fan stage installation with the acoustic barrier wall in place. Downstream fixed microphones were not used with the wall installed because of acoustic blockage. The sideline traversing microphone probe may be seen to the left of the research fan stage in both photographs.

\section{Results and Discussion}

\section{A. Aerodynamic Performance}

The results indicate that there was an increase in stage thrust with increased bypass nozzle area at most rotor speeds. However, aerodynamic data taken concurrently with acoustic testing were limited to rotor and stator assembly thrust and torque due to the need for clean airflow within the model (removal of protruding measuring rakes, etc.). Therefore, the thrust values presented herein are from rotating and static force balance measurements made during acoustic testing. Thrust values are available for the rotor and for the stator/nacelle/afterbody assembly, which includes the stators, flight nacelle, and aft inner bypass flowpath representing the outer boundary of the simulated core hardware downstream of the bypass nozzle. Fan stage thrust measurements are a combination of the rotor thrust from rotating force balance measurements and stator/nacelle/afterbody thrust from static force balance measurements obtained simultaneously during testing. Results from these force balance measurements provided valid rotor and stage thrust values at tunnel test conditions.

Figure 9 shows the increase in corrected weight flow, and figure 10 shows the corrected stage thrust, respectively as a function of the corrected rotor tip speed for the three bypass nozzle designs tested. Figure 9 shows a consistent increase in corrected weight flow with increased nozzle area at all rotor test speeds, except for the high flow nozzle at the highest rotor speeds-100 percent corrected rotor design speed and above. Figure 10 likewise shows a consistent increase in stage thrust with increased nozzle area at all rotor test speeds, except for the high flow nozzle at the highest rotor speeds. The accuracy of the measured thrust is $\pm 10 \mathrm{lbf}$, or \pm 0.25 percent of the full scale measurement range $(4000 \mathrm{lbf})$ of the combined balances. A description of the technique used for force balance performance measurement can be found in reference 16.

Figure 11 shows the percent change in corrected stage thrust for the three nozzle flows. The results of figure 11 were obtained by inspecting the thrust levels at particular rotor tip speeds in figure 9. Stage thrust levels for the +5 percent flow nozzle were about 3 percent higher than for the reference nozzle at approach rotor speed, and slightly more than 2 percent higher at cutback and takeoff rotor speed. Even higher thrust levels are seen for the +7.5 percent flow nozzle at approach and cutback rotor speeds. However, thrust levels for this nozzle area drop off toward takeoff (design) rotor speed—indicating degrading stage flow conditions for this nozzle at high rotor speeds. 


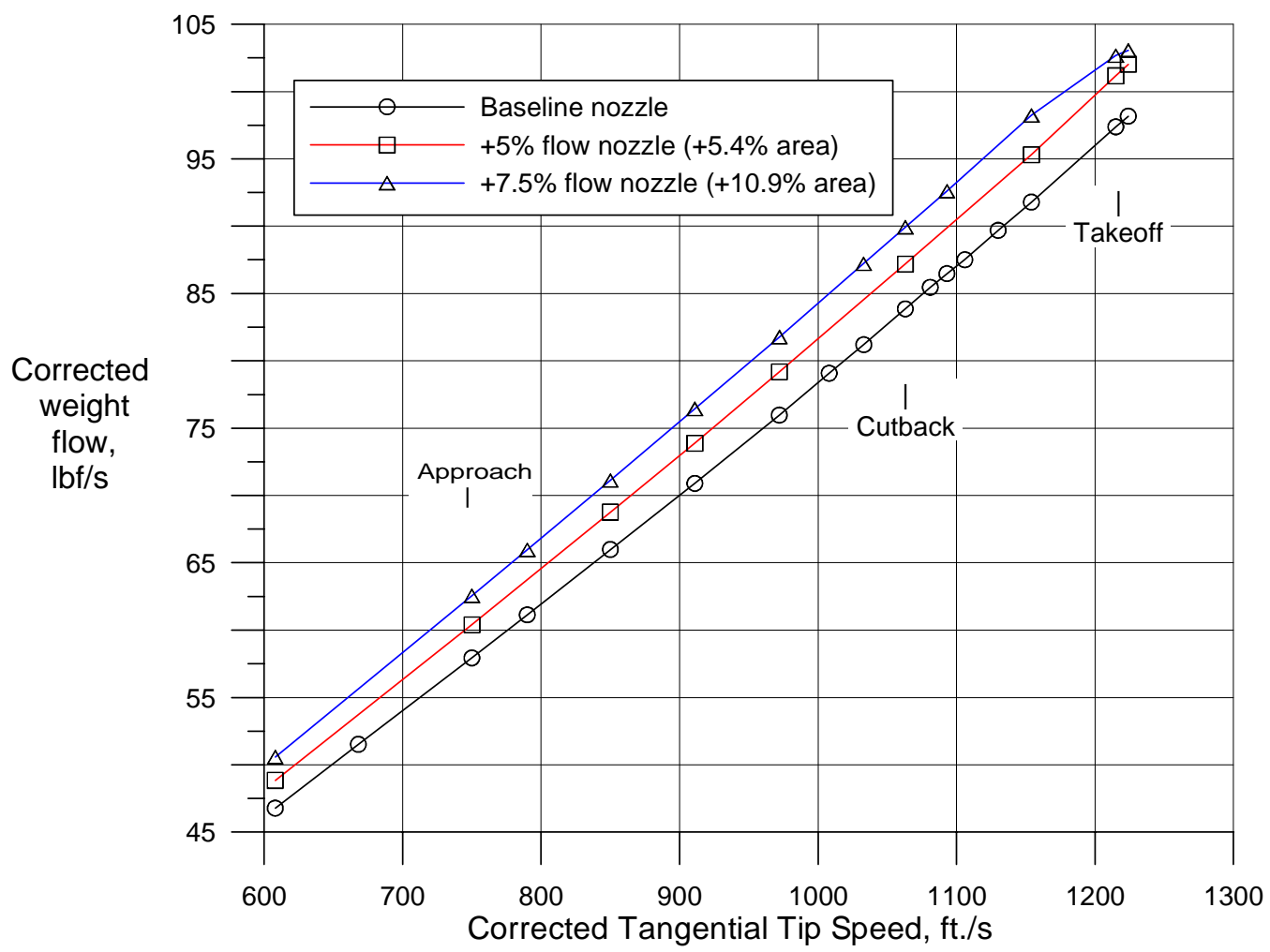

Figure 9.-Corrected weight flow as a function of corrected tangential tip speed for three bypass nozzle flows.

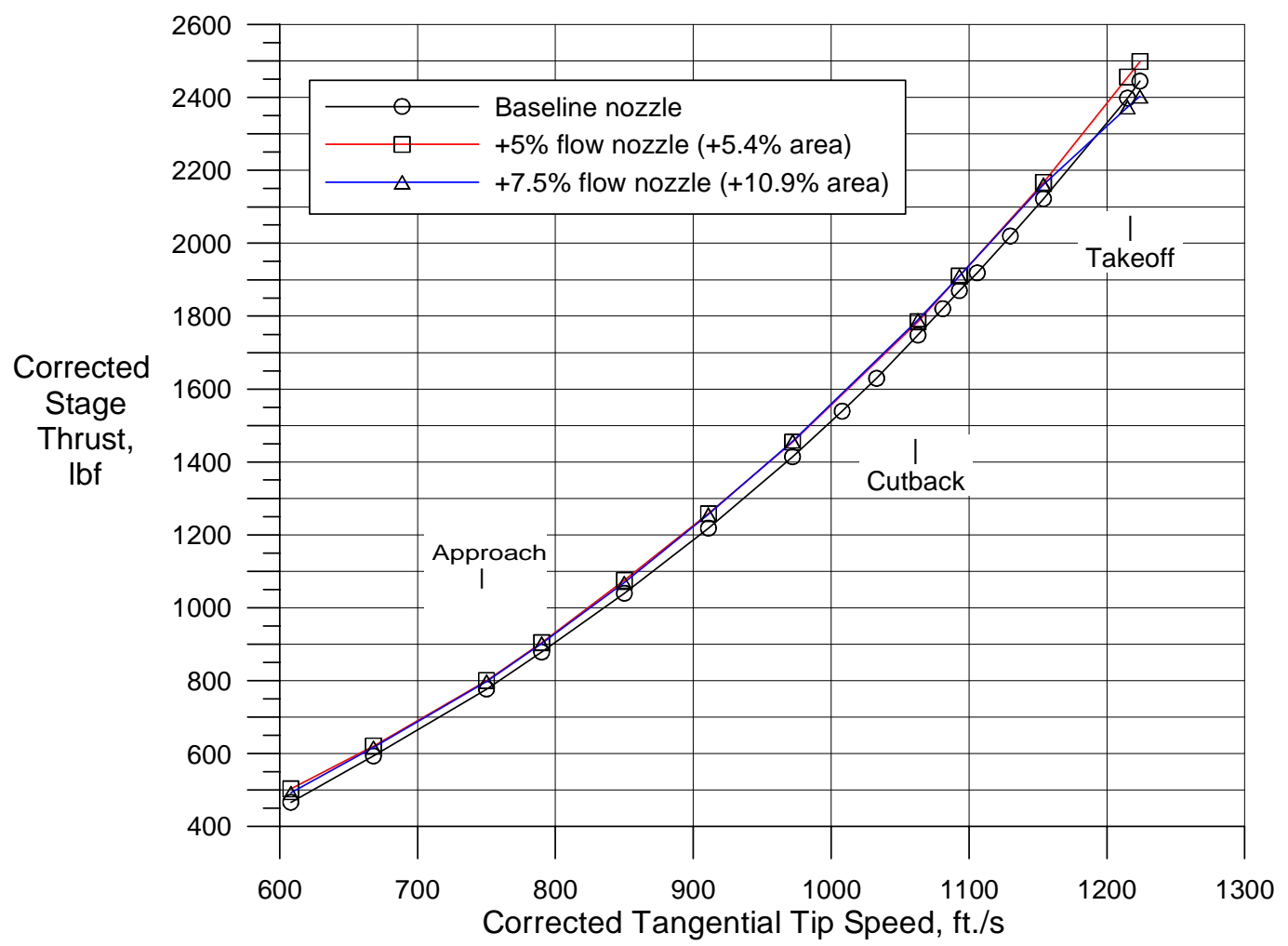

Figure 10.-Corrected stage thrust as a function of corrected tangential tip speed for three bypass nozzle flows. 


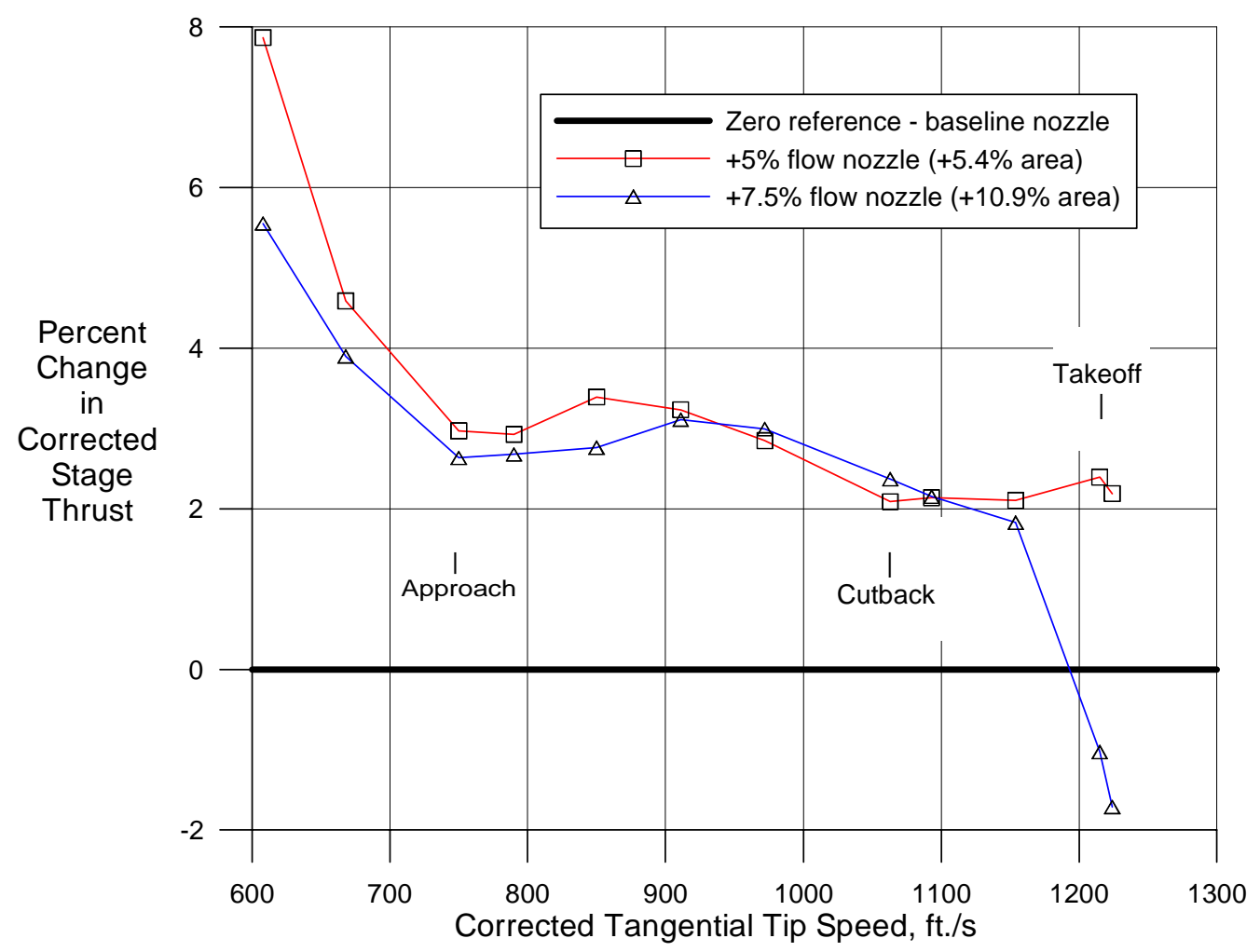

Figure 11.-Percent change in stage thrust as a function of bypass nozzle flow.

Figures 12 and 13 show the measured rotor thrust as a function of corrected rotor tip speed. Unlike the stage thrust, the rotor thrust typically showed a reduction with increasing nozzle area. The rotor thrust levels for the +5 percent flow nozzle were 1 percent less than that for the reference nozzle at approach rotor speed, and 2 percent lower at higher rotor speeds. Rotor thrust levels for the +7.5 percent flow nozzle were significantly lower, showing a 4 percent thrust reduction relative to reference nozzle thrust at approach rotor speed, 6 percent less at cutback speed, and dropping to around 10 percent less at takeoff rotor speed. Figures 12 and 13 demonstrate that the stator thrust is more than compensating for the losses in the rotor, producing an overall increase in stage thrust as the nozzle area is opened.

The thrust results (figs. 10 to 13) suggest that there is lower rotor blade loading associated with increased nozzle area and higher axial flow. The stator, however, appears to have been more effective in generating significantly more thrust with increased nozzle flow. This is likely due to the increase in lift in the thrust component direction because of the higher axial velocity with higher weight flow through the model. The exception is the most open nozzle area (+7.5 percent flow) at rotor speeds above 87.5 percent, where the thrust results show that both the rotor and stage performance has degraded significantly. This may be due to shock losses over a larger spanwise section of the blade because of the higher axial flow velocity associated with the higher weight flows compared to that for the other two nozzles at the same fan speeds. The flow over the rotor becomes transonic at 87.5 percent design speed. Another possibility is a stronger blade-to-blade passage shock that may also be deeper within the passage, causing a disruption of the flow over the rotor blades resulting in a drop in blade loading. 


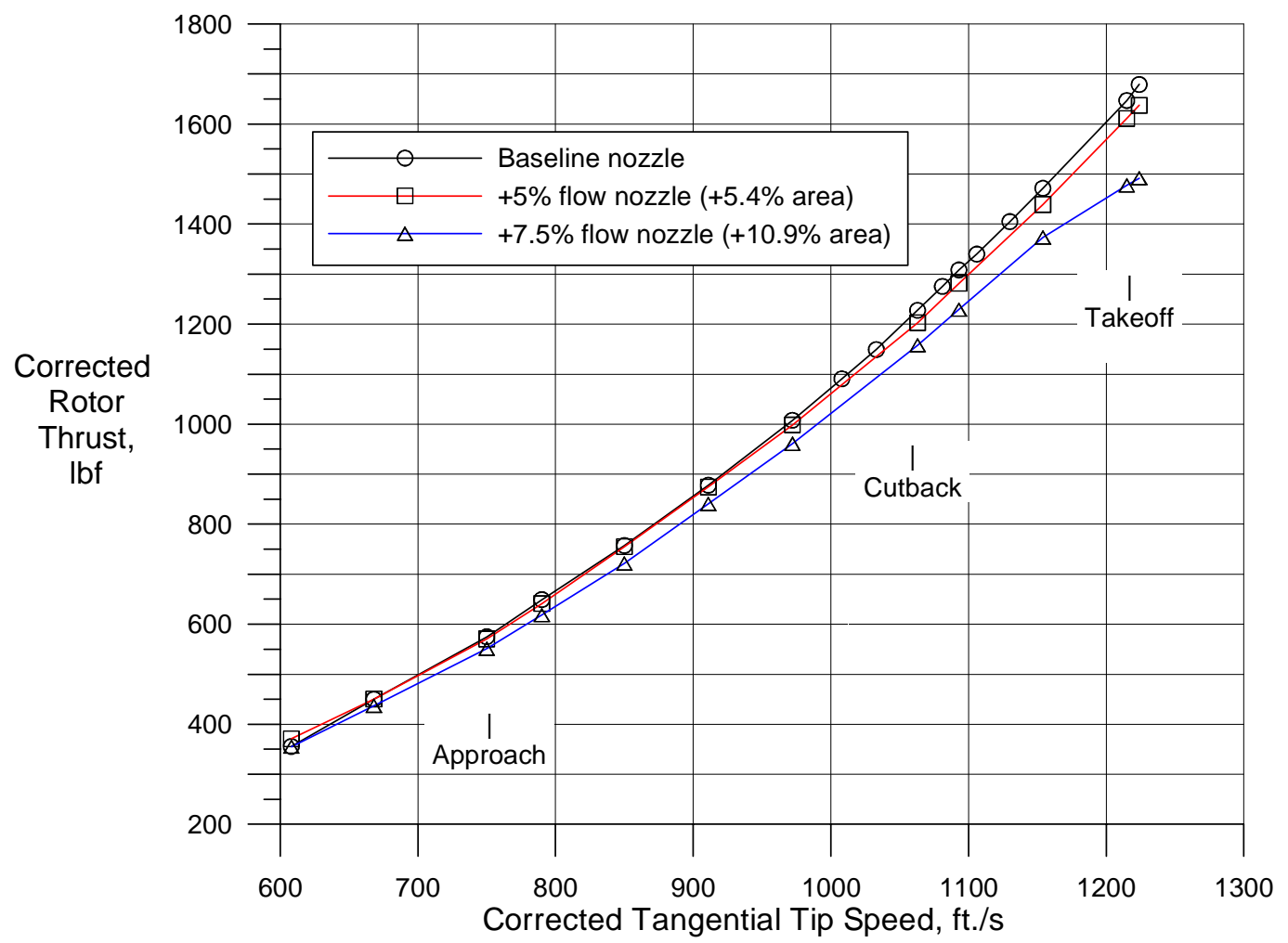

Figure 12.-Corrected rotor thrust as a function of corrected tangential tip speed for three bypass nozzle flows.

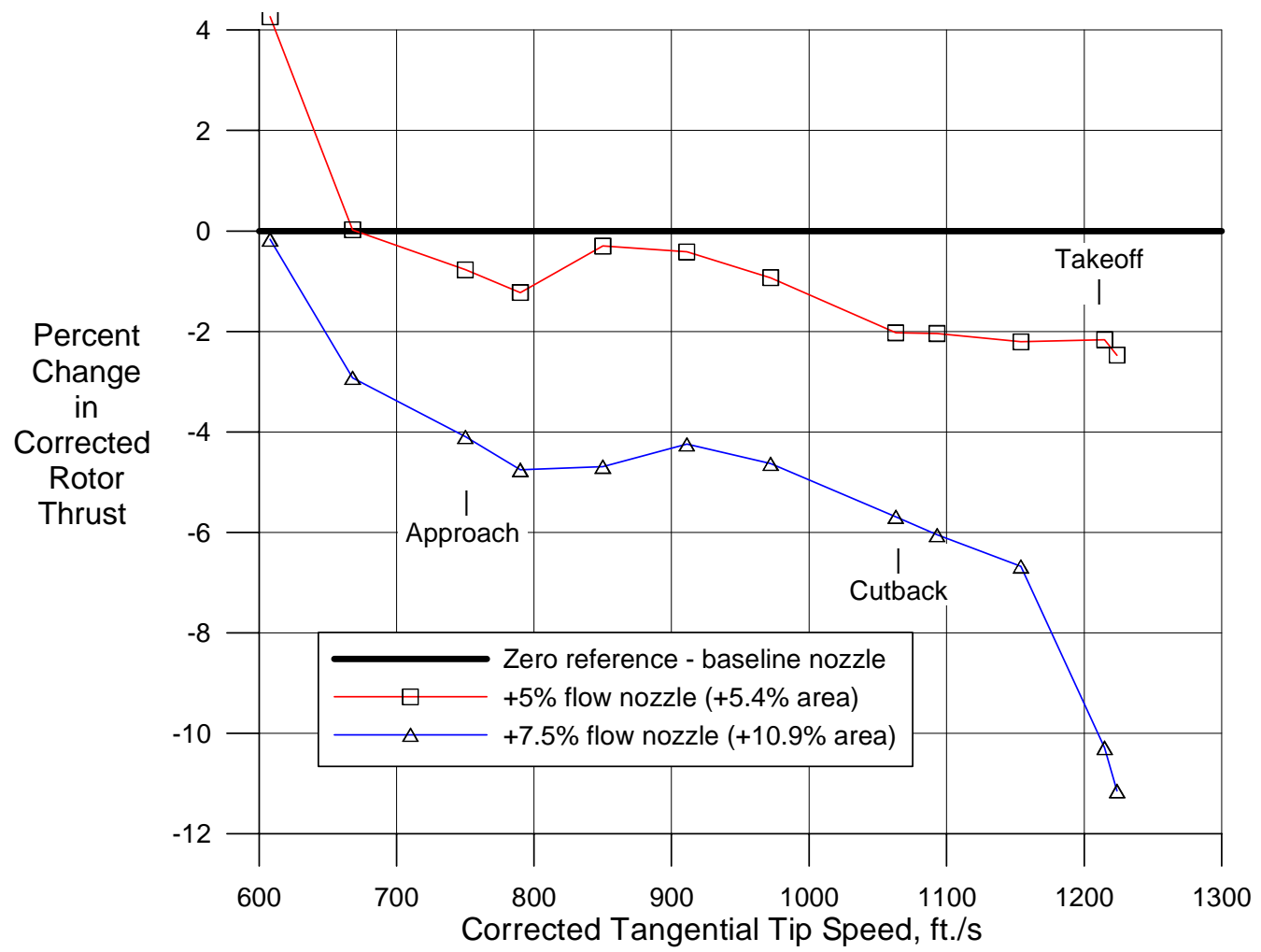

Figure 13.-Percent change in rotor thrust as a function of bypass nozzle flow. 


\section{B. Acoustic Data Reduction}

All of the fan stage acoustic data were acquired at 0.10 tunnel Mach, which is sufficient to achieve acoustic flight effect. ${ }^{17}$ Sideline data are presented in terms of emission angles. The emission angles are related to the geometric or observed angles by the relationship

$$
\Theta_{\mathrm{em}}=\Theta_{\text {geom }}-\sin ^{-1}\left(\mathrm{M}_{0} \sin \Theta_{\text {geom }}\right)
$$

where $\Theta_{\mathrm{em}}$ and $\Theta_{\text {geom }}$ are, respectively, the emission and observed sideline angles, and $\mathrm{M}_{0}$ is the test section Mach number. The observed angles for the sideline translating microphone probe are then 25 to $130^{\circ}$, and the three fixed microphones measure aft observed angles of 136,147 , and $158^{\circ}$. This angular range was sufficient to define the sideline noise profile for this aft-dominated fan stage for subsequent EPNL calculations.

Digital acoustic data were processed as constant bandwidth spectra. Spectra were acquired and averaged at each translating probe or fixed mic position with 5.9 and $59 \mathrm{~Hz}$ bandwidths. These constant bandwidth spectra were electronically merged and used to generate 1/3-octave spectra, using the $5.9 \mathrm{~Hz}$ bandwidth results for lower $1 / 3$ octave frequencies, and the $59 \mathrm{~Hz}$ bandwidth results for the higher frequencies. Sound power level (PWL) spectra were calculated from the SPL spectra assuming spherical symmetry through the range of sideline data acquisition. Possible noise contributions outside the sideline range were ignored.

\section{Acoustic Results}

Figure 14 shows the OAPWL as a function of stage thrust for the three test nozzle areas. The OAPWL was calculated from the $59 \mathrm{~Hz}$ BW spectra over a 1 to $50 \mathrm{~K}$ frequency range for sideline emission angles from 25 to $158^{\circ}$. There is a significant noise decrease associated with increasing nozzle flow-especially at lower rotor speeds. Figure 15 shows the change in OAPWL for the more open nozzles relative to that for the baseline, sea level design nozzle. These delta OAPWL were measured at constant thrust levels interpolated from the curves of figure 14 .

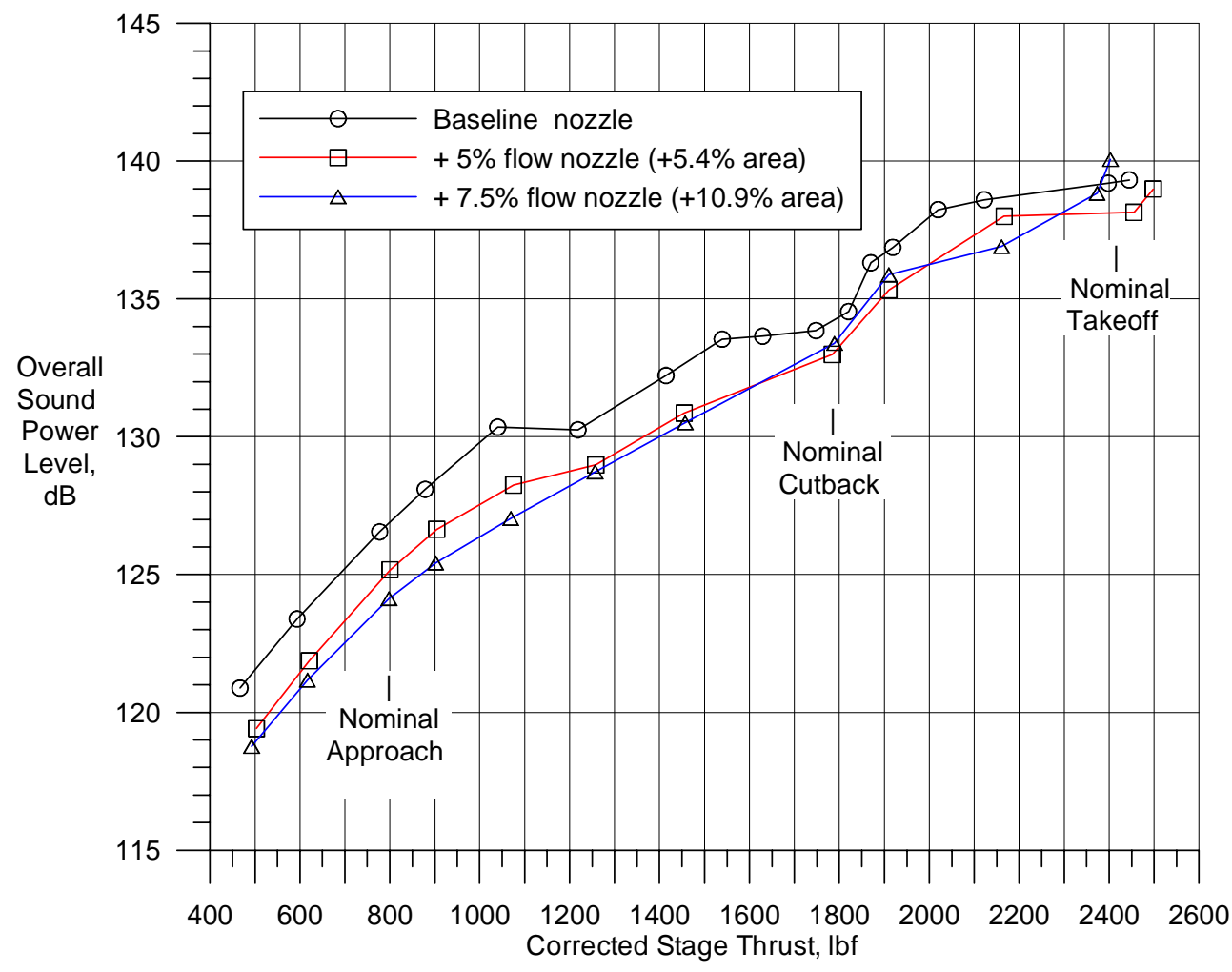

Figure 14.-OAPWL as a function of corrected stage thrust showing potential noise benefits with increased bypass nozzle flow. 


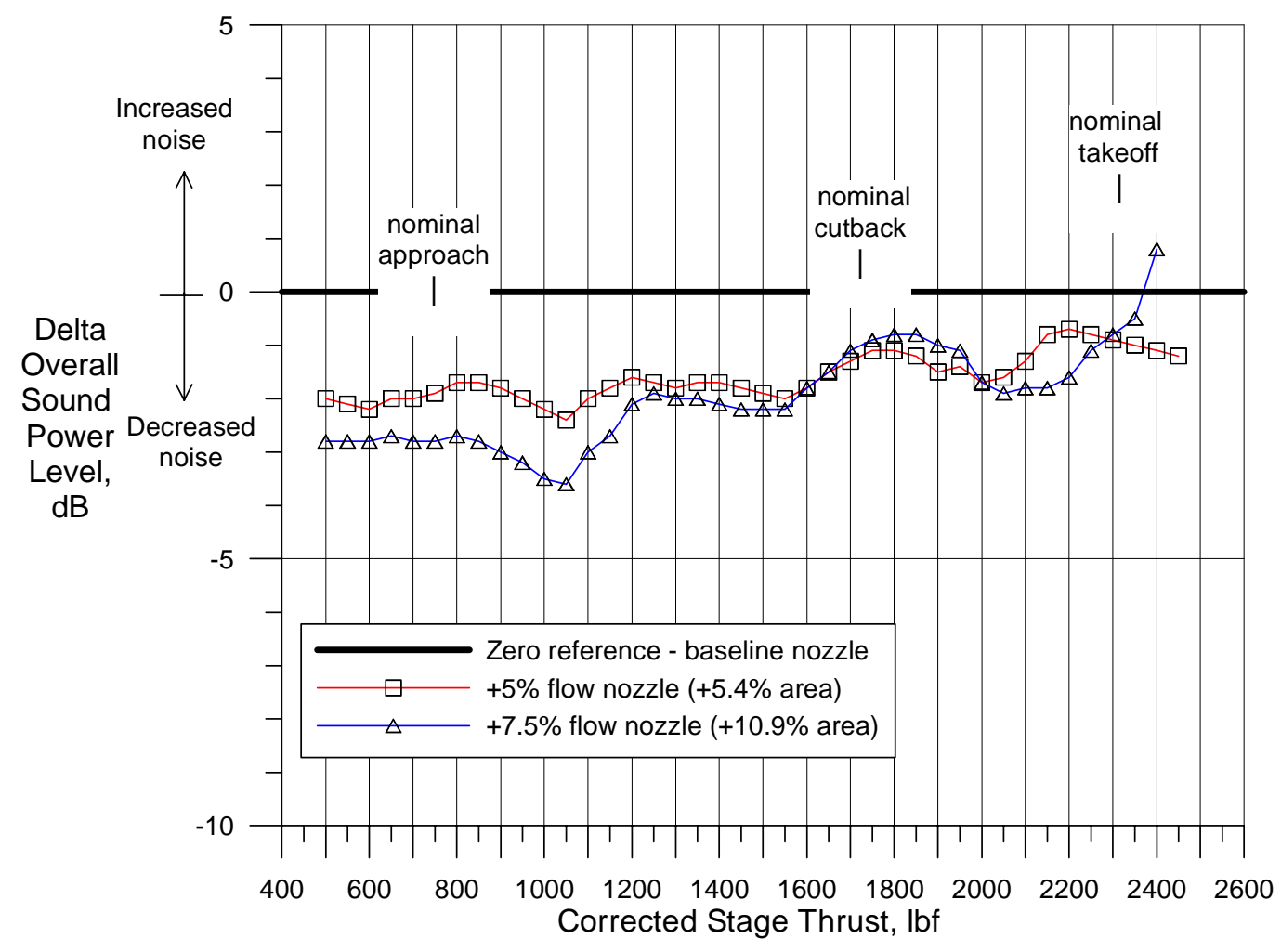

Figure 15. - Delta OAPWL relative to the baseline nozzle as a function of corrected stage thrust.

Increasing the nozzle flow by 5 percent resulted in a $2 \mathrm{~dB}$ noise reduction at rotor speeds up to cutback, and around a $1 \mathrm{~dB}$ reduction at higher rotor speeds. Further increasing the nozzle flow to +7.5 percent gave noise reductions of about $3 \mathrm{~dB}$ relative to the baseline nozzle at lower rotor speeds (near approach) and a $2 \mathrm{~dB}$ noise reduction at intermediate rotor speeds. However, this more open nozzle resulted in higher noise levels at the highest rotor speeds, likely associated with degraded rotor performance with the +7.5 percent flow nozzle near design speed.

The reduced rotor thrust with the more open nozzles (figs. 12 and 13) likely corresponds to a lower rotor incidence angle and reduced rotor turbulence at these conditions. This would result in the observed reductions in broadband noise level with increased nozzle flow. Also, higher rotor axial flow velocity with increased nozzle area would result in stronger rotor wakes impinging on the stator and consequently the observed increase in rotor/stator interaction tone levels.

Figures 16 and 17 show corresponding OAPWL with the acoustic barrier wall in place (forward radiating noise). Interestingly, the noise reduction with increased nozzle flow (fig. 16) is even greater than what was observed without the barrier wall. The results of figure 14 were interpolated to show the change in noise level relative to the baseline nozzle at a constant stage thrust (fig. 17), Increasing the nozzle flow by +5 percent resulted in about a $2 \mathrm{~dB}$ noise reduction at subsonic tip speeds, and up to $4 \mathrm{~dB}$ at design speed. Further increasing the nozzle flow to +7.5 percent gave noise reductions around $4 \mathrm{~dB}$ at subsonic tip speeds and as much as $7.5 \mathrm{~dB}$ near design rotor speed. The forward radiating noise levels near designated cutback (transonic rotor tip speed) were mixed, showing additional noise for the +7.5 percent flow nozzle, and no change with the +5 percent flow nozzle. Noise levels at, or slightly above cutback may be influenced by the relative strengths of the multiple pure tones (MPT) which appear as the rotor flow becomes transonic. The rotor axial velocity for a particular tip speed increases with the more open nozzles. Consequently, the rotor relative airflow would reach transonic speeds and MPT generation at somewhat lower tip speeds as the nozzle flow is increased. 


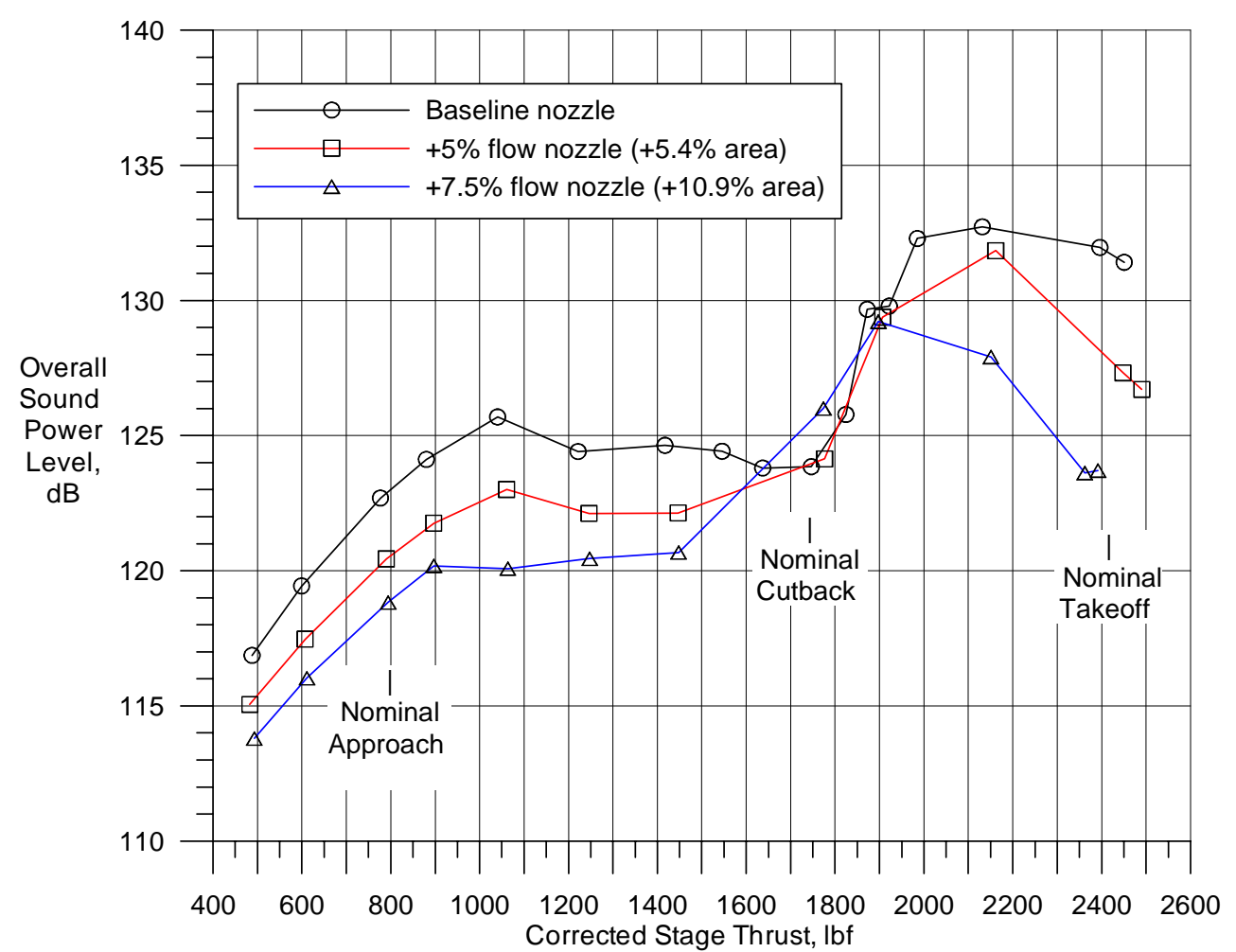

Figure 16.- Inlet radiating OAPWL as a function of corrected stage thrust showing potential noise benefits with increased bypass nozzle flow (acoustic barrier wall in place).

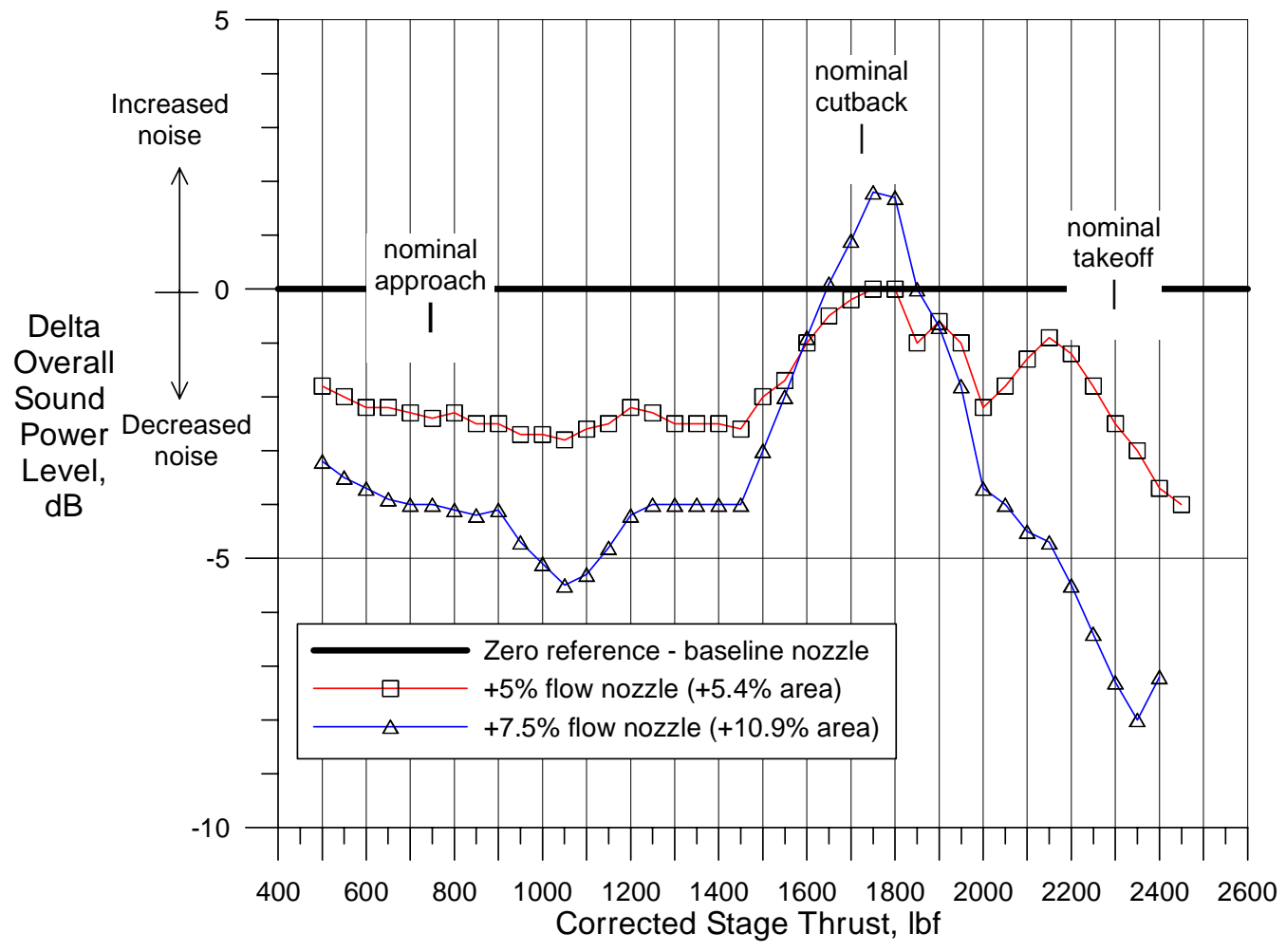

Figure 17.-Delta OAPWL relative to the baseline nozzle as a function of corrected stage thrust (acoustic barrier wall in place). 
Noise reductions associated with increased nozzle flow extend over a significant frequency range. Figures 18 to 20 show sound power level spectra (PWL) at the three fan stage rating conditions. Blade/vane numbers for this fan stage result in the fundamental rotor-stator interaction tone being essentially cut off at lower rotor speeds. Broadband noise levels at 61.7 percent design rotor speed (fig. 18) are up to $3 \mathrm{~dB}$ lower for the +5 percent flow nozzle and $6 \mathrm{~dB}$ lower for the +7.5 percent flow nozzle relative to noise levels for the baseline nozzle. The $2 \mathrm{BPF}$ interaction tone (cut on) shows a small increase with increasing nozzle flow. It is possible that the rotor relative velocity and subsequent wake interaction with the stator, increases with nozzle flow.

There is a significant increase in BPF tone level with increasing nozzle flow at 87.5 percent rotor speed (fig. 19). Again, this may be explained by the argument that increasing the nozzle flow effectively increases the rotor relative velocity and wake strength, resulting in a stronger rotor/stator interaction tone. MPT generation becomes more evident with increasing nozzle flow at this rotor speed. (This earlier onset of MPTs with increased nozzle flow is consistent with the OAPWL results of figure 17) There is a more modest reduction in broadband noise of about $2 \mathrm{~dB}$ with both increased flow nozzles. The noise "hump" at about half BPF for the baseline nozzle is unexplained.

Multiple pure tone generation is well established at design rotor speed (fig. 20). There is a small increase in BPF level with increasing nozzle flow at design rotor speed while the broadband noise levels show a modest reduction with increased nozzle flow.

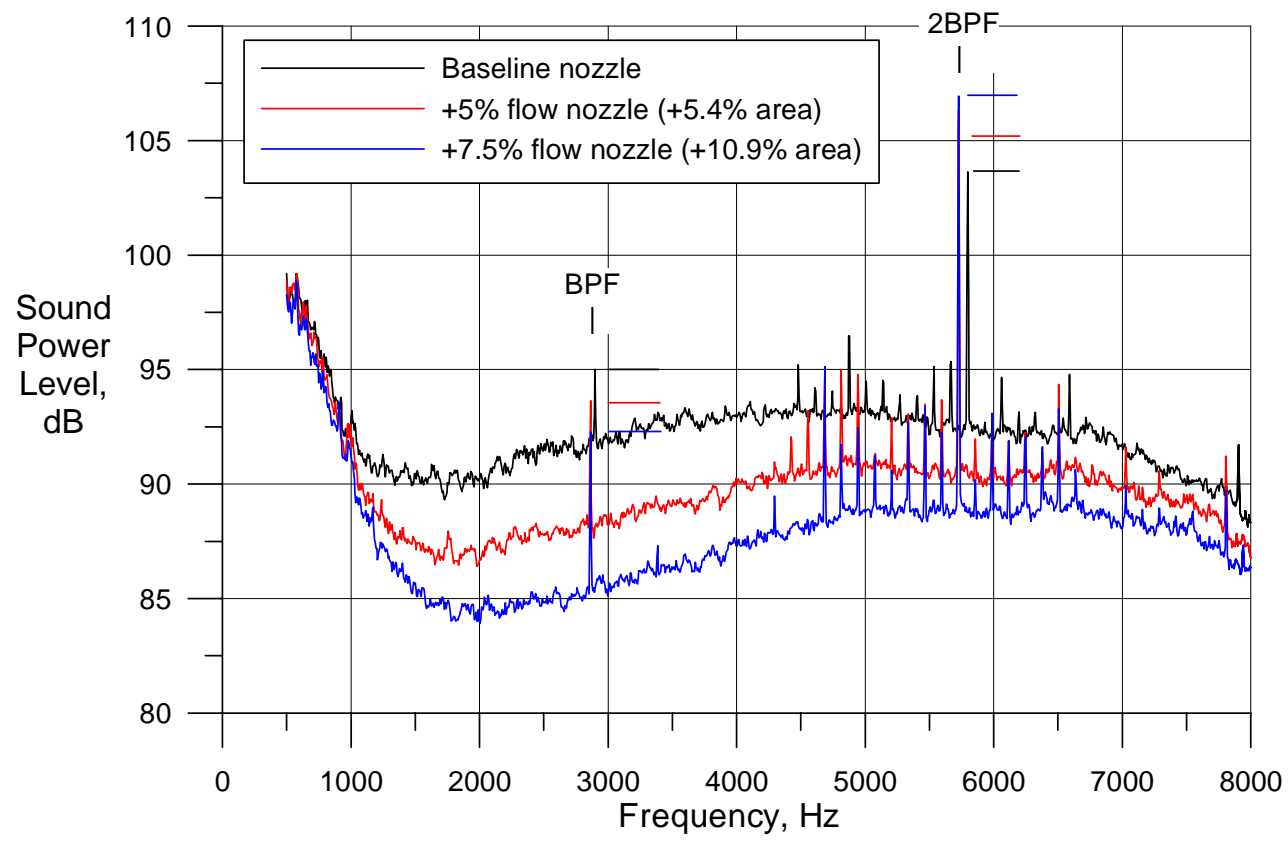

Figure 18.- Sound power level spectra at 61.7 percent rotor design speed (designated approach speed, $5.9 \mathrm{~Hz}$ bandwidth, no barrier wall). 


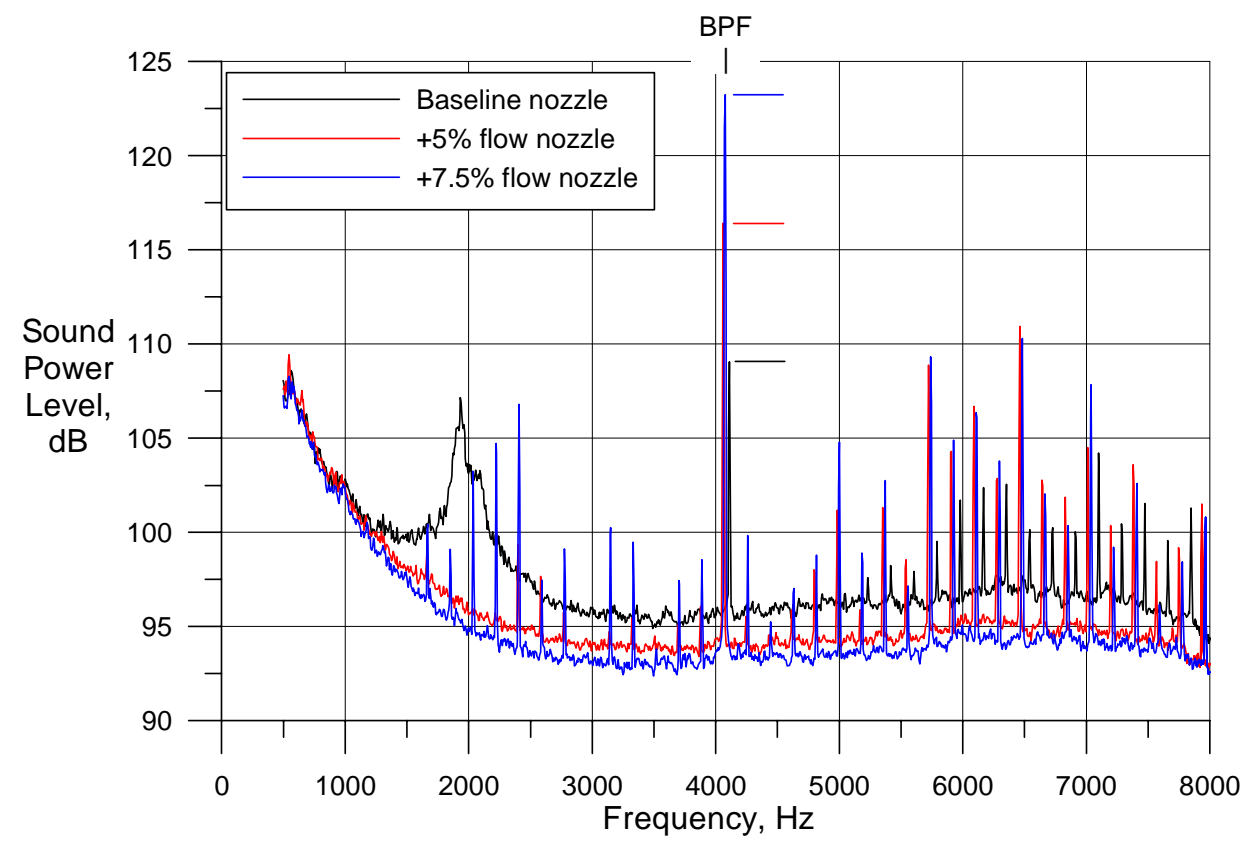

Figure 19.-Sound power level spectra at 87.5 percent rotor design speed (designated cutback speed, $5.9 \mathrm{~Hz}$ bandwidth, no barrier wall).

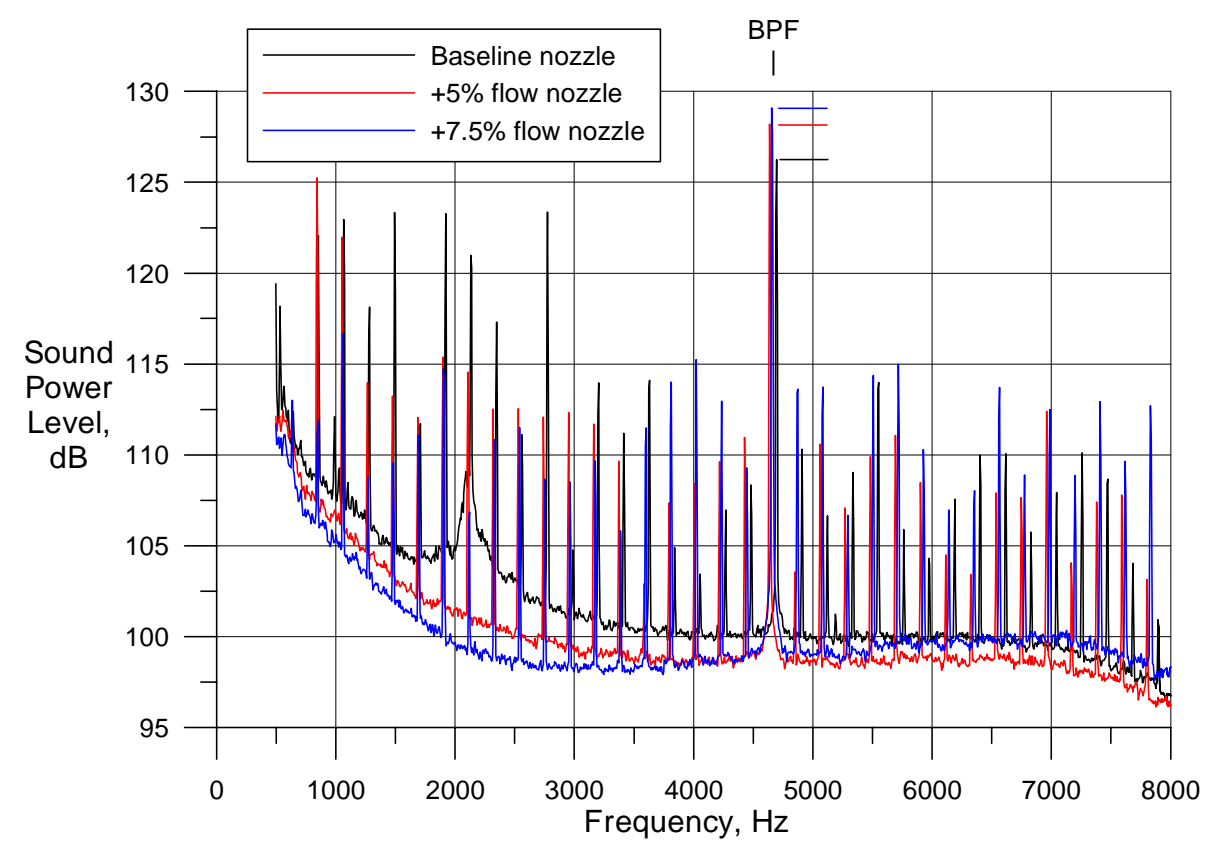

Figure 20.-Sound power level spectra at 100 percent rotor design speed (designated takeoff speed, $5.9 \mathrm{~Hz}$ bandwidth, no barrier wall). 
Observed noise reductions with increased nozzle area typically occurred at all measured sideline angles. Figures 21 to 23 show $59 \mathrm{~Hz}$ bandwidth sound pressure level directivities for the first two rotor tones (BPF and 2BPF) and representative broadband noise at, respectively 61.7, 87.5, and 100 percent design rotor speed. At 61.7 percent rotor speed the residual BPF tone (fig. 21(a)) was reduced by about $2 \mathrm{~dB}$ with the +5 percent flow nozzle, and about $5 \mathrm{~dB}$ with the +7.5 percent flow nozzle. The 2BPF tone (fig. 21(b)) showed a similar reduction with increased nozzle flow at some sideline angles, although this result is not in good agreement with the corresponding PWL spectra of figure 18. The representative broadband directivities between BPF and 2BPF (fig. 21(c)) again show a nominal $2 \mathrm{~dB}$ reduction with the +5 percent flow nozzle and $5 \mathrm{~dB}$ reduction with the +7.5 percent flow nozzle.

The designated "cutback" rotor speed (87.5 percent design) is at transonic tip speed where rotor-alone noise begins to dominate the tones. Increased nozzle flow at this rotor speed results in a significant increase in BPF tone level (fig. 22(a)) as much $15 \mathrm{~dB}$ at the $70^{\circ}$ sideline emission angle. Also, this increased noise is not uniform over all sideline angles, but somewhat localized from 40 to $110^{\circ}$ emission angles. It is possible that the BPF tone (which is just cut on at this rotor speed) is more strongly cut on with higher rotor relative velocities associated with increased nozzle flow. There is a slight reduction in the 2BPF tone (fig. 22(b)) with increased nozzle flow, and essentially no change in broadband level with increased nozzle flow (fig. 22(c)).

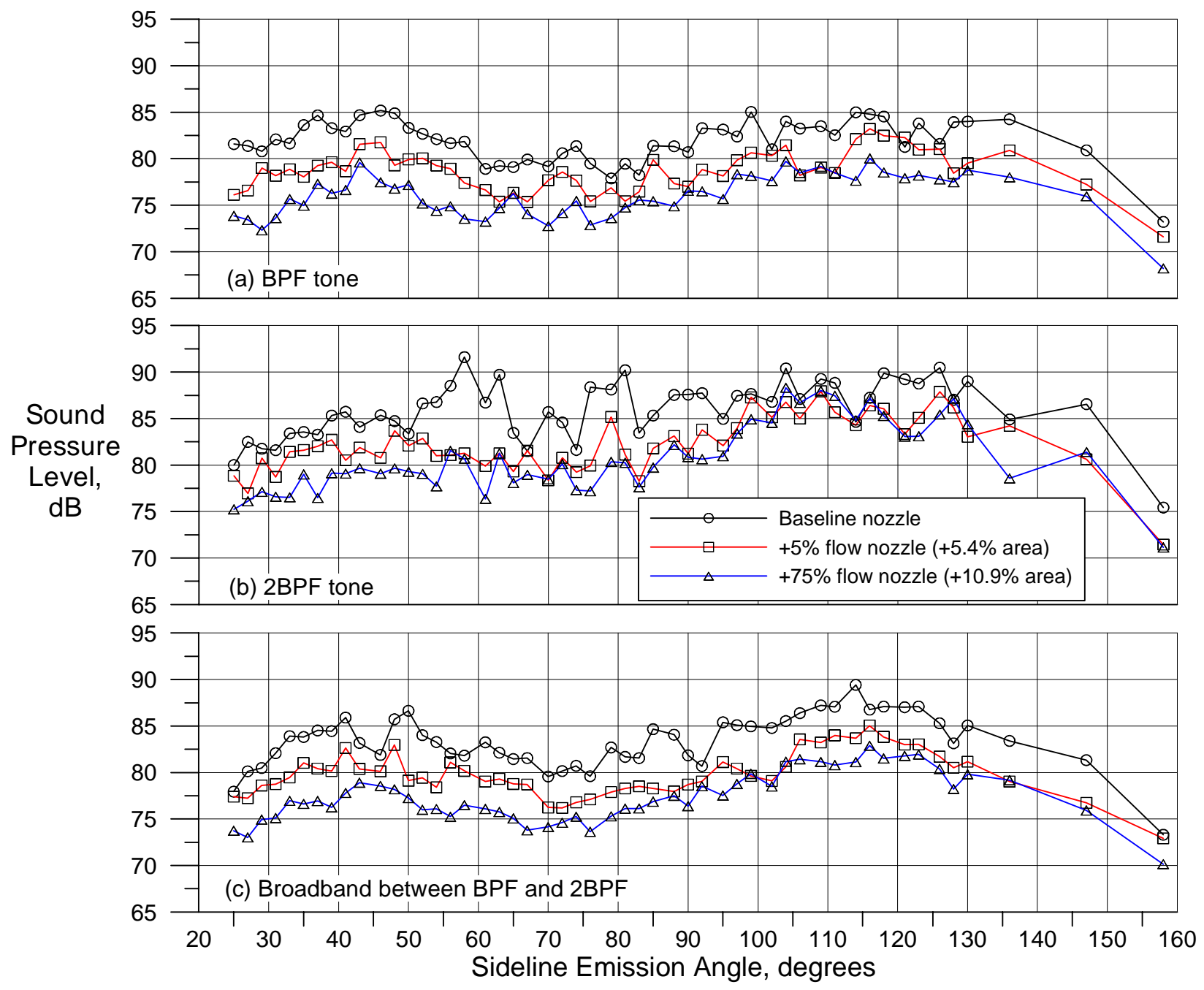

Figure 21.-Sound pressure level directivities at 61.7 percent rotor design speed (89 in. sideline, no barrier wall, $59 \mathrm{~Hz}$ bandwidth). 
The BPF tone level at design rotor speed (fig. 23(a)) shows little consistent change with nozzle flow. The BPF tone is primarily rotor-alone noise at this higher rotor speed (including MPTs). However, there is about a $5 \mathrm{~dB}$ noise reduction in the $2 \mathrm{BPF}$ tone at this rotor speed (fig. 23(b)) with the +7.5 percent flow nozzle. The representative broadband noise levels between BPF and 2BPF (which would have MPT content) is only slightly reduced with increased nozzle flow at design rotor speed (fig. 23(c)).

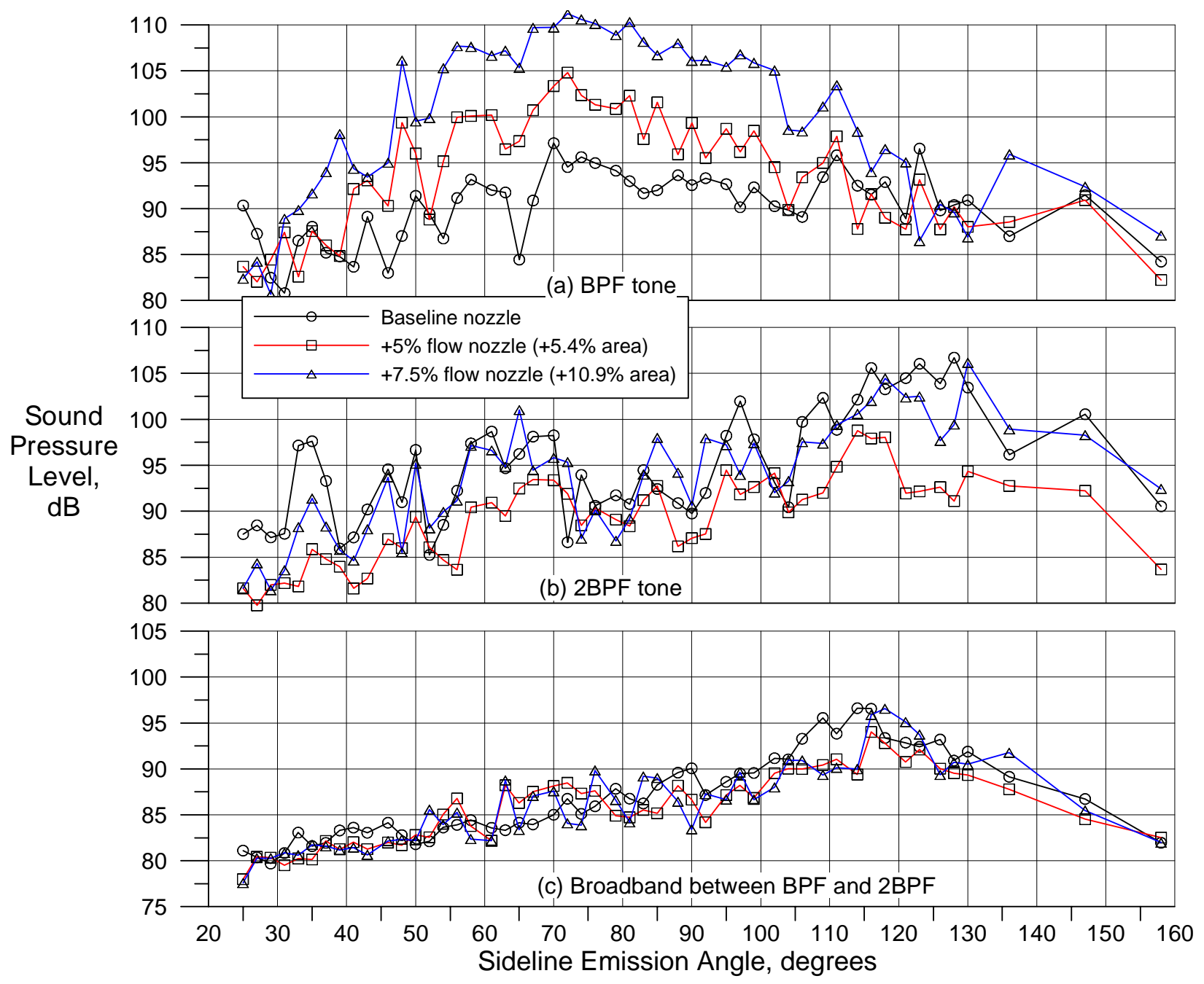

Figure 22.- Sound pressure level directivities at 87.5 percent rotor design speed (89 in. sideline, no barrier wall, $59 \mathrm{~Hz}$ bandwidth). 


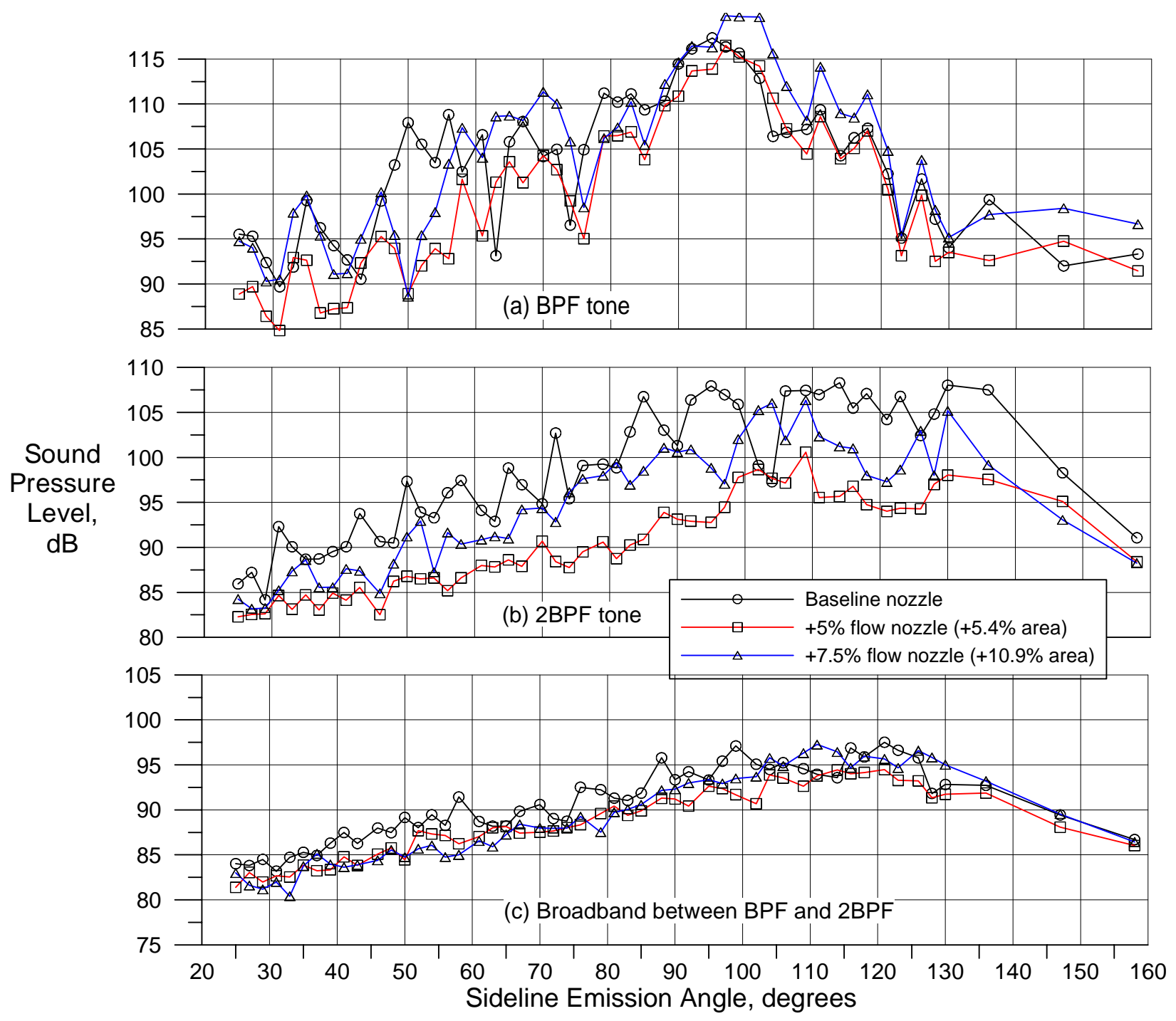

Figure 23.- -Sound pressure level directivities at 100 percent rotor design speed (89 in. sideline, no barrier wall, $59 \mathrm{~Hz}$ bandwidth).

\section{Implications for Turbofan Engine Noise Reduction}

Aeroacoustic results shown in this report suggest that a variable area bypass exhaust nozzle for a typical turbofan engine may be an effective way to further decrease engine fan stage noise and possibly realize a concurrent slight thrust increase. The baseline fixed-area bypass nozzle in this test was sized for maximum stage performance at sea level conditions. Turbofan engine bypass exhaust nozzles are normally sized for maximum performance at the portion of the aircraft flight profile where most of the flight time is spent-typically at the cruise condition. Increasing the nozzle flow within the envelope defined by desirable engine performance reduced the fan stage noise in this scale model test. Thus, it may be desirable to employ a variable area engine bypass exhaust nozzle as a technique to reduce fan stage noise levels at all rotor operating speeds. Even the addition of a limited position variable area bypass nozzle, in order to reduce mechanical complexity and weight, might be an effective retrofit to existing turbofan engines to control fan stage noise and realize additional noise reduction without sacrificing aerodynamic performance. 


\section{References}

${ }^{1}$ Woodward, R.P., Hughes, C.E., Jeracki, R.J., and Miller, C.J., "Fan Noise Source Diagnostic Test - Far-Field Acoustic Results,” AIAA-2002-2427, June 2002.

${ }^{2}$ Hughes, C.E., “Aerodynamic Performance of Scale-Model Turbofan Outlet Guide Vanes Designed for Low Noise,” AIAA-2002-0374, January 2002.

${ }^{3}$ Hughes, C.E., Jeracki, R.J., and Miller, C.J., "Fan Noise Source Diagnostic Test - Rotor Alone Aerodynamic Performance Results," AIAA-2002-2426, June 2002.

${ }^{4}$ Podboy, G.G., Krupar, M.J., Helland, S.M., and Hughes, C.E., "Steady and Unsteady Flow Field Measurements Within a NASA 22 Inch Fan Model,” AIAA-2002-1033, January 2002.

${ }^{5}$ Podboy, G.G., Krupar, M.J., Hughes, C.E., and Woodward, R.P., "Fan Source Diagnostic Test - LDV Measured Flow Field Results," AIAA-2002-2431, June 2002.

${ }^{6}$ Heidelberg, L.J., “Fan Noise Source Diagnostic Test - Tone Model Structure Results,” AIAA-2002-2428, June 2002.

${ }^{7}$ Dahl, M.D., and Woodward, R.P., "Comparison Between Design and Installed Acoustic Characteristics of the NASA Lewis 9- by 15-Foot Low Speed Wind Tunnel Acoustic Treatment,” NASA TP-2996, April 1990.

${ }^{8}$ Dahl, M.D., and Woodward, R.P., "Background Noise Levels Measured in the NASA Lewis 9- by 15-Foot Low Speed Wind Tunnel,” NASA TP-274, November 1992.

${ }^{9}$ Woodward, R.P., and Dittmar, J.H., "Background Noise Levels Measured in the NASA Lewis 9- by 15-Foot Low-Speed Wind Tunnel,” NASA TM-106817, AIAA-95-0720, January 1995.

${ }^{10}$ Woodward, R.P., Lucas, J.G., and Stakolilch, E.G., “Acoustic and Aerodynamic Performance of a 1.83-Meter- (6-Ft) Diameter 1.2-Pressure-Ratio Fan (QF-6),” NASA TN D-7809, December 1974.

${ }^{11}$ Woodward, R.P., Lucas, J.G., and Balombin, J.G., "Acoustic and Aerodynamic Performance of a 1.5-Pressure-Ratio, 1.83-Meter (6 Ft.-) Diameter Fan Stage for Turbofan Engines (QF-2),” NASA TM X-3521, April 1977.

${ }^{12}$ Woodward, R.P., and Glaser, F.W., "Effect of Inflow Control on Inlet Noise of a Cut-on Fan,” AIAA Journal, Vol. 19, No. 3, March 1981, pp. 387-392.

${ }^{13}$ Gliebe, P.R., "The Effect of Throttling on Forward Radiated Fan Noise,” AIAA-79-0640, March 1979.

${ }^{14}$ Ginder, R.B. and Newby, D.R., “An Improved Correlation for the Broadband Noise of High-Speed Fans,” AIAA Journal of Aircraft, Vol. 14, No. 9, September 1977, pp. 844-849.

${ }^{15}$ Tyler, J.M. and Sofrin, T.G., “Axial Flow Compressor Noise Studies,” SAE Trans, Vol. 70, 1962, pp. 309-332.

${ }^{16}$ Jeracki, R.J., “Model Engine Performance Measurement from Force Balance Instrumentation,” NASA/TM-1998-208486, AIAA-98-3112, July 1998.

${ }^{17}$ Chestnutt, D., “Flight Effects of Fan Noise,” NASA CP-2242, January 1982. 


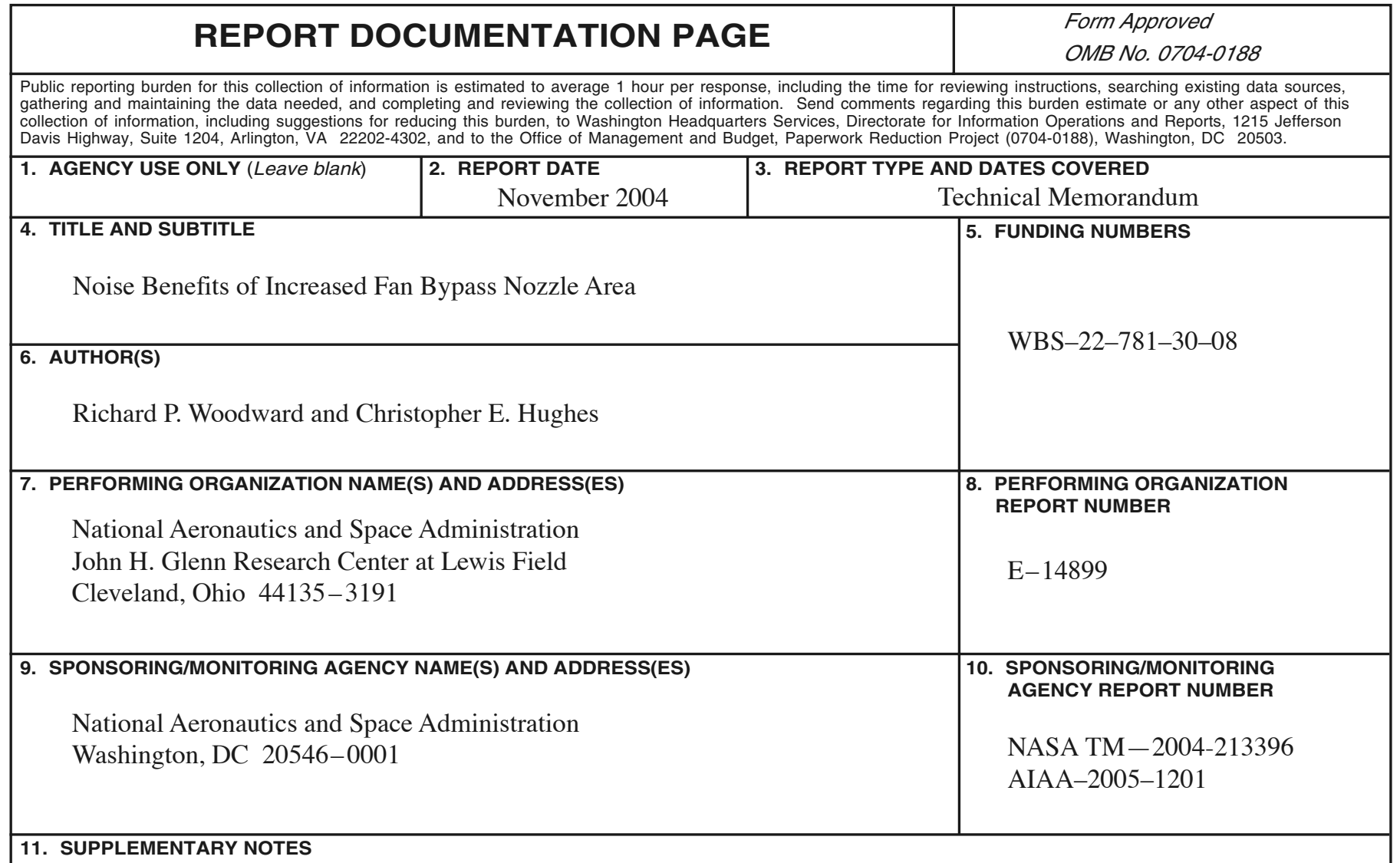

Prepared for the 43rd Aerospace Sciences Meeting and Exhibit sponsored by the American Institute of Aeronautics and Astronautics, Reno, Nevada, January 10-13, 2005. Responsible person, Richard P. Woodward, organization code RTA, 216-433-3923.

12a. DISTRIBUTION/AVAILABILITY STATEMENT

12b. DISTRIBUTION CODE

Unclassified - Unlimited

Subject Categories: 01, 07, and 02

Distribution: Nonstandard

Available electronically at http://gltrs.grc.nasa.gov

This publication is available from the NASA Center for AeroSpace Information, 301-621-0390.

13. ABSTRACT (Maximum 200 words)

An advanced model turbofan (typical of current engine technology) was tested in the NASA Glenn 9- by 15-Foot Low

Speed Wind Tunnel (9- by 15-Foot LSWT) to explore far field acoustic effects of increased bypass nozzle area. This fan stage test was part of the NASA Glenn Fan Broadband Source Diagnostic Test, second entry (SDT2) which acquired aeroacoustic results over a range of test conditions. The baseline nozzle was sized to produce maximum stage performance for the engine at a high altitude, cruise point condition. However, the wind tunnel testing is conducted near sea level conditions. Therefore, in order to simulate and obtain performance at other aircraft operating conditions, two additional nozzles were designed and tested - one with a +5 percent increase in weight flow $(+5.4$ percent increase in nozzle area compared with the baseline nozzle), sized to simulate the performance at the stage design point conditions, and the other with a +7.5 percent increase in weight flow $(+10.9$ percent increase in nozzle area), sized for maximum weight flow with a fixed nozzle at sea level conditions. Measured acoustic benefits with increased nozzle area were very encouraging, showing overall sound power level (OAPWL) reductions of 2 or more dB while the stage thrust actually increased by several percentage points except fro the most open nozzle at takeoff rotor speed where stage performance decreased. These noise reduction benefits were seen to primarily affect broadband noise, and were evident throughout the range of measured sideline angles.

14. SUBJECT TERMS

Aircraft noise; Jet aircraft noise; Acoustic emission 23

\begin{tabular}{|c|c|c|}
\hline $\begin{array}{c}\text { 17. SECURITY CLASSIFICATION } \\
\text { OF REPORT } \\
\text { Unclassified }\end{array}$ & $\begin{array}{c}\text { 18. SECURITY CLASSIFICATION } \\
\text { OF THIS PAGE } \\
\text { Unclassified }\end{array}$ & $\begin{array}{c}\text { 19. SECURITY CLASSIFICATION } \\
\text { OF ABSTRACT } \\
\text { Unclassified }\end{array}$ \\
\hline
\end{tabular}

NSN 7540-01-280-5500

Standard Form 298 (Rev. 2-89)

Prescribed by ANSI Std. Z39-18 298-102 

